ICTD Working Paper 122

The Role of Social Influence in Enforcing Tax Compliance: Experimental Evidence from Nigeria

Adedeji Adeniran, Mma Amara Ekeruche and Chukwuka Onywkwena

June 2021 
The Role of Social Influence in Enforcing Tax Compliance: Experimental Evidence from Nigeria Adedeji Adeniran, Mma Amara Ekeruche and Chukwuka Onywkwena

ICTD Working Paper 122

First published by the Institute of Development Studies in June 2021

(c) Institute of Development Studies 2021

ISBN: [978-1-78118-818-7]

DOI: $\underline{10.19088 / I C T D .2021 .011}$

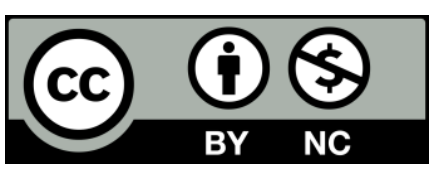

This is an Open Access paper distributed under the terms of the Creative Commons Attribution Non-Commercial 4.0 International license, which permits downloading and sharing provided the original authors and source are credited - but the work is not used for commercial purposes. http://creativecommons.org/licenses/by-nc/4.0/legalcode

\section{Available from:}

The International Centre for Tax and Development at the Institute of Development Studies, Brighton BN1 9RE, UK

Tel: +44 (0) 1273606261

Email: info@ictd.ac

Web: www.ictd.ac/publication

IDS is a charitable company limited by guarantee and registered in England

Charity Registration Number 306371

Charitable Company Number 877338 


\title{
The Role of Social Influence in Enforcing Tax Compliance: Experimental Evidence from Nigeria
}

\author{
Adedeji Adeniran, Mma Amara Ekeruche and Chukwuka Onywkwena
}

\begin{abstract}
Summary
Economic development is linked with increased state capacity including the ability to mobilise domestic tax resources. For many developing countries, high levels of informality are a major constraint in this regard. Yet, economic incentives like changing the tax rate or increasing the filling and audit rate can be ineffective in a highly informal economic structure. In this paper, we explore possible roles for behavioural interventions such as sharing information about peers' tax behaviour to engineer higher tax compliance. Based on an artefactual field experiment among own account workers in Nigeria, we find that information interventions can play an important role in ensuring tax compliance. Specifically, targeting information around what people can directly observe can be a way to improve tax compliance. Providing information on punishment or good practices that appeal to feelings of morality yields higher tax compliance.
\end{abstract}

Keywords: tax compliance, peer effect, economic experiment, informal sector, Nigeria.

Adedeji Adeniran is the Director of Education and Governance at the Centre for the Study of the Economies of Africa, Abuja, Nigeria. His research interests cut across sustainable development, fiscal policy, public economics and experimental economics.

Mma Amara Ekeruche is a Research Fellow at the Centre for the Study of the Economies of Africa, Abuja, Nigeria. Her research interests cut across energy, development economics, and macroeconomic and fiscal management.

Chukwuka Onywkwena is the Executive Director of the Centre for the Study of the Economies of Africa, Abuja, Nigeria. His research interests include foreign direct investment. 


\section{Contents}

Summary 3

Acknowledgements 5

$\begin{array}{ll}\text { Introduction } & 6\end{array}$

$\begin{array}{lll}1 & \text { Overview of tax compliance in Nigeria } & 7\end{array}$

$2 \quad$ Literature review $\quad 9$

$3 \quad$ Theoretical framework 11

3.1 The two-stage tax decision framework 11

3.2 Incorporating the peer effect 12

$4 \quad$ Experimental design $\quad 14$

$\begin{array}{ll}4.1 & \text { Experimental treatments } \\ & 16\end{array}$

$\begin{array}{lll}4.2 & \text { Empirical method } & 16\end{array}$

$\begin{array}{lll}5 & \text { Empirical results } & 17\end{array}$

$\begin{array}{lll}5.1 & \text { Descriptive analysis } & 17\end{array}$

$\begin{array}{lll}5.2 & \text { Regression results } & 18\end{array}$

$\begin{array}{ll}5.3 & \text { Effect of tax knowledge and governance } \\ \end{array}$

$6 \quad$ Policy implications $\quad 21$

Appendices $\quad 23$

Appendix $1 \quad$ Summary statistics 23

$\begin{array}{lll}\text { Appendix } 2 & \text { Instruction for the control group } & 23\end{array}$

$\begin{array}{lll}\text { Appendix } 3 & z \text {-Tree interface for the experiment } & 25\end{array}$

$\begin{array}{lr}\text { References } & 29\end{array}$

Tables

Table 1

Table 2

Table 3

Table 4

Demographic composition of the participants $\quad 15$

$\begin{array}{ll}\text { Experimental treatments } & 16\end{array}$

Main regression results 20

Regression results accounting for governance and tax knowledge $\quad 21$

Figures

Figure 1

Figure 2

Nigerian tax to GDP ratio against other African countries

8

Figure 3

Personal income revenue in Nigeria

Figure 4

Tax compliance rate among participants over ten rounds

Figure 5

Filing rate among participants

Reporting rate among participants 


\section{Acknowledgements}

The authors wish to thank the team at ICTD and the Nigerian Tax Research Network (NTRN) for the grant and for editorial support throughout this project. We thank CSEA staff who supported the process of conducting the experiment, in particular, Precious Akanonu, Joseph Ishaku and Lateef Akanni for suggestions and validation of the experimental protocol. We also thank Samuel Chukwudi, Amarachi Nkata, Chioma Nwanna and Barnabas Osonwa, who assisted in subject recruitment and provided technical support during the experiment. 


\section{Introduction}

Improving tax compliance is one of the most pressing policy challenges facing African countries (Sy and Sow 2016). With the tripartite problems of high informality, weak state capacity for efficient tax collection, and low financial inclusion, tax systems rely more on selfassessment and voluntary compliance (Okello 2014). This has resulted in huge tax gaps for many countries and shallow fiscal space for active economic management. The International Monetary Fund (IMF 2018) estimated that sub-Saharan African countries have an annual tax gap of $\$ 50-80$ billion, which exceeded the total overseas development assistance to the continent in 2018.

Recent literature has emphasised the use of non-pecuniary mechanisms (behavioural factors) as alternative tools to improve compliance including through the social influence of peers (Hallsworth, List, Metcalfe and Vlaev 2017; Alm, Bloomquist and McKee 2015), appealing to patriotism (Moore 2004) and signalling improved political accountability and service delivery (Tyler 2006; Kirchler, Hoelzl and Wahl 2008).

In this paper, we examine the role of social influence on compliance when individuals are exposed to information on the tax behaviour of their peers. For example, showing tax defaulters information about the percentage of people already paying tax has been found to improve compliance (Hallsworth et al. 2017). However, the literature also demonstrates that it is the information content that matters for compliance, as different information types, either full or partial information, could yield disparate outcomes (Alm et al. 2015).

In this paper, we test the basic predictions of the social influence theory in an artefactual field experiment among own account workers in Nigeria. Own account workers are those identified either as self-employed or who do not engage any other employees on a continuous basis. It is estimated that over 99 per cent of firms in Nigeria are micro enterprises or own account workers and they largely operate in the informal sector (Nigerian Bureau of Statistics and the Small and Medium Enterprises Development Agency 2019). This informal economic structure partly explains the low tax compliance in Nigeria, as 73 per cent of the labour force are not within the tax net (Adeyemi and Adeduro 2020). In this context, governments mostly resort to non-pecuniary mechanisms to mobilise resources from the informal sector.

We set up a laboratory experiment that allows for differentiation of the information content about peers that individuals can observe. In one setting, the participants were shown all taxrelated information about their peers, including how many were filing their taxes, the reported income, amount of tax paid, number of people audited, and amount of penalty paid by defaulters. In the second setting, the only information shown was the amount of tax paid by the highest taxpayers in their group. In the third setting, only information about those penalised for tax evasion was shown. The three treatments were compared with the control group in which no information was shown. We found that the compliance level when the full information is revealed was worse than the outcome when no information was shown. However, in scenarios when only partial information was shown (second and third settings), the tax compliance improved significantly relative to the full information treatment and in the control group.

This paper contributes to existing literature on the subject in three ways. First, this study is novel with regard to the choice of experimental approach applied to Nigeria. Existing studies on tax compliance in Nigeria have adopted a case study approach or use observational data (Modugu and Anyaduba 2014; de Gramont 2015). However, phenomena like social influence are difficult to isolate in observational data given many confounding variables and the presence of other behavioural attributes. Experimental data is crucial to sidestep these 
concerns as it allows for concentration on only the variables of interest. The empirical evidence from this study will extend the literature in this area and expand the policy menu from which tax authorities can draw to achieve better compliance.

Second, the paper contributes to experimental studies on the social influence theory of tax compliance. Notable earlier studies in this strand of the literature include Cummings, Martinez-Vazquez, McKee and Torgler 2009, Alm, Cherry, Jones and McKee 2010, Alm et al. 2015, and Luttmer and Singhal 2014. The focus of this study on the informal sector is distinct and separates it from the earlier literature, whose findings relate more to the entire economy or formal sector.

Third, the study relates to literature on the effectiveness of information interventions. Studies on different information interventions to improve development outcomes have yielded mixed results (Besley and Burgess 2002; Chong, De La O, Karlan and Wantchekon 2015). Kosec and Wantchekon (2020) make a useful contribution to this literature by highlighting the conditions under which information is effective. Specifically, they propose that an information intervention is pro-development if it is relevant to the recipient who, in tandem, has the power and incentive to act on it. Our finding also reinforces these conditions regarding effectiveness of information with the need to focus on specific and targeted information within a reference group.

The rest of this paper is structured as follows. Section 1 provides a brief review of tax compliance in Nigeria and the policy environment. Section 2 reviews the literature on social influence theory. Section 3 describes the theoretical model which motivates the design of our experiment. In section 4, we detail the experimental procedure and implementation strategy for the study. Section 5 presents the experimental results from both the non-parametric and econometric analyses. The policy implications of the results are discussed in section 6.

\section{Overview of tax compliance in Nigeria}

Despite its large economic size and population, Nigeria's tax base and compliance level remain abysmally low. In 2018, the total tax/GDP ratio stood at 5.7 per cent (OECD 2019). As shown in Figure 1, Nigeria has one of the lowest tax/GDP ratios in Africa, compared to other low-middle income countries in Africa. Resource curse alone does not seem to explain Nigeria's low compliance level as resource rich and fragile states like Congo are doing much better. Nigeria's underperformance in revenue collection signals that its optimal tax capacity has not been reached especially with respect to the non-oil sector. Oil revenue accounts for 49.6 per cent of general government revenue in 2019, yet the oil sector represents only 10 per cent of the national income (Central Bank of Nigeria 2020: 16). The susceptibility of the economy to persistent external shocks is also evident in the nature of resource dependency and low budget performance. 
Figure 1 Nigerian tax to GDP ratio compared to other African countries

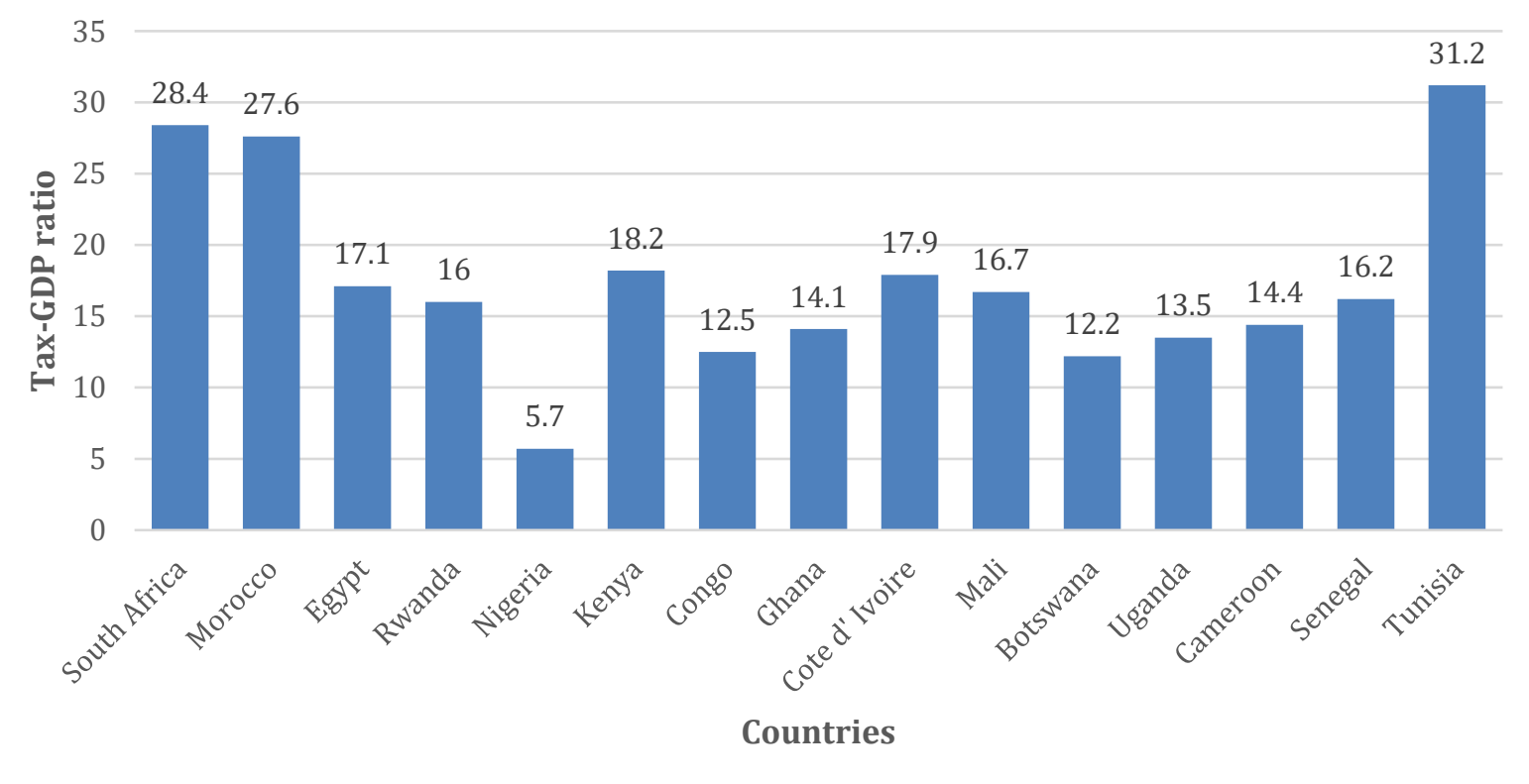

Data source: OECD (2019).

Personal income tax accounts for 11 per cent of total government receipts in 2017 (Figure 2). While recent trends indicate progress is being made, tax performance is not at the desirable magnitude. Comparatively, South Africa, with less than a third of the Nigerian labour force, had a personal income tax of about NGN (Nigerian Naira) 9.7 trillion (US\$31.7 billion) in $2017,{ }^{1}$ while Nigeria received NGN802 billion (US\$2.6 billion) over the same period (Nigerian Natural Resource Charter 2019). With the recent volatility in oil price and weak global demand depressing prices, the government is increasingly focused on non-oil revenue through efforts to widen the tax base and compliance level.

\section{Figure 2 Personal income revenue in Nigeria}

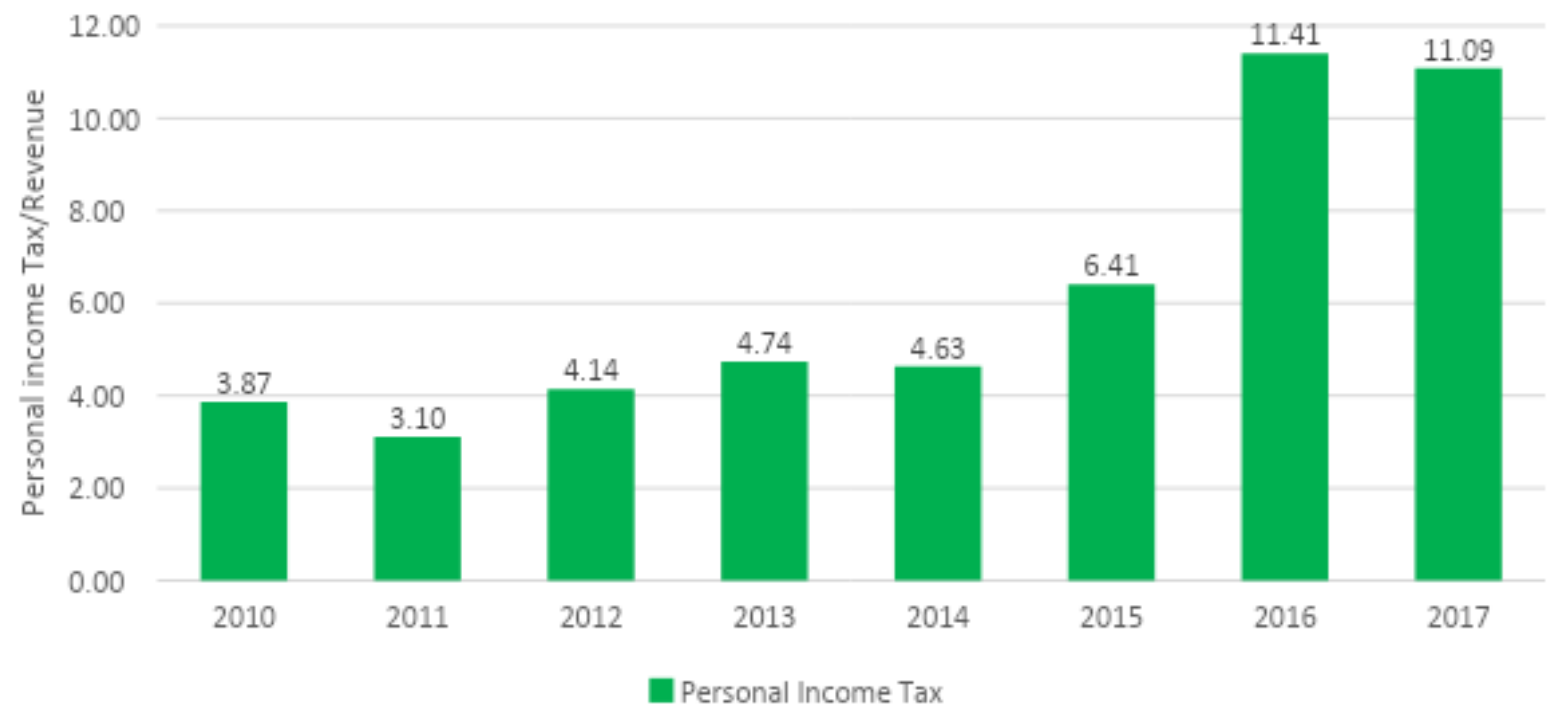

Data source: OECD 2020.

In the last three years, several reforms have been introduced at the national and sub-national levels. In 2017, the Voluntary Assets and Income Declaration Scheme (VAIDS) was initiated

1 https://www.cbn.gov.ng/rates/exrate.asp?year=2017 Exchange rate US\$1 = N 306. 
to allow individuals and corporate entities to regularise their tax status for previous years or pay severe penalties if audited and found not to have filed accurate tax information. This policy hinges on the capacity of the government to identify and punish tax evaders. More recently, the government enacted the 2020 Finance Bill to harmonise the different tax policies and widen the tax net to include digital platforms with significant economic presence in Nigeria. The bill deployed a 'carrot and stick' approach with the introduction of mechanisms to foster compliance and simplify the tax payment system, while at the same time elevating the penalties for tax defaulters.

The Nigerian Federal Ministry of Finance reported that the VAIDS programme raised an additional NGN70 billion (US $\$ 228$ million) $^{2}$ in revenue (Olalekan 2020), representing less than 1 per cent of additional revenue per annum since the inception of the policy. The trend in tax performance suggests the need for a better policy mix to improve tax compliance. Specifically, an effective combination of deterrence policy with other behavioural approaches could substantially improve tax performance. Evidence for this is not far-fetched, as one of Africa's most impressive success stories of tax reform took place in Lagos State, Nigeria, between 2004 and 2011. Lagos State Government increased its revenue from less than NGN3 billion (US $\$ 33$ million) per annum in $1999^{3}$ to over NGN30 billion (US $\$ 98$ million) per annum in $2016^{4}$ without changing the tax rate (de Gramont 2015). The reform encompassed digitalising the tax system to reduce fraud, improving the capacity of tax administrators, and enhancing service delivery for taxpayers (de Gramont 2015; Goodfellow and Owen 2018).

Key components of the reform, however, are the redefining of the social contract between government and citizens, and public enlightenment. The state government embarked on a massive public awareness campaign called '\#Taxdidit' to educate the public on the importance of tax and its contribution to local economic development. This was backed up by concrete actions through rejigging the transport and waste disposing systems and other tangible benefits for the citizens. According to de Gramont (2015), strategic use of information was crucial to improving tax compliance in Lagos State. For example, information on the penalty for defaulters and the benefits of paying were included as part of the campaign. These are examples of improving tax morale through appealing to patriotism and rebuilding trust through improved service delivery. This example illustrates that tax reform is a holistic package in which economic fundamentals and social norms play a role.

The underlying economic structure in Nigeria also supports the use of behavioural approaches to tax compliance. The informal sector is dominant and combined with the absence of a strong identification system, this weakens the capacity to rely mainly on economic deterrence. In fact, there is limited replication of the Lagos State success story due to high informality among other sub-national units. In this instance, other behavioural interventions such as tax morale and strategic information sharing could be deployed to improve compliance levels. In this paper, we demonstrate the potential for this.

\section{Literature review}

The individual decisions to file an income return and pay tax are driven by social and economic factors. The standard economic theory describes this decision setting with a costbenefit framework where a rational economic agent weighs the benefits of under-reporting compared to the probability of detection and penalty for tax evasion (Allingham and Sandmo 1972). While many of the testable predictions of the standard economic models have been

\footnotetext{
https://www.cbn.gov.ng/rates/exrate.asp?year=2020 Exchange rate US $\$ 1=\mathrm{N} 306.96$

https://www.cbn.gov.ng/IntOps/ExchRatePolicy.asp Exchange rate US $\$ 1=\mathrm{N} 91.83$.

https://www.cbn.gov.ng/rates/exrate.asp?year=2016 Exchange rate US $\$ 1=\mathrm{N} 305.21$.
} 
confirmed empirically (Grundmann and Lambsdorff 2017; Duch and Solaz 2015), evidence also points to their incompleteness and the need to account for social norms and influence in understanding tax compliance (Fjeldstad, Snow, Miles and Lettl 2012; Guerra and Harrington 2018; Enachescu, Olsen, Kogler, Zeelenberg, Breugelmans and Kirchler 2019).

One of the key behavioural explanations of tax compliance is the social influence theory, which predicts that the decision to evade taxes is shaped by social norms and the degree of tax compliance within an individual's reference group. When individuals think of (or observe) their peers paying taxes, their own commitment to pay taxes is strengthened (Hallsworth et al. 2017; Alm et al. 2015; Alm and Liu 2017). This can also result when the individual forms an expectation about the probability of detection based on the experience of their peers. The prevailing social norms about the importance of taxation, which are likewise derived from one's immediate social group, will also influence tax behaviour (Posner 2000).

An extensive body of work has emerged to test the role of information about peers in tax compliance behaviour. Ali, Fjeldstad and Sjursen (2014) use survey data on attitudes towards tax evasion in four African countries (Tanzania, Uganda, Kenya, and South Africa) to test different theories of tax compliance, including social influence theory. Their study finds significant evidence of social influence theory only in Tanzania, although less robust compared to the standard economic model. However, the social norms and influence are difficult to measure and test using survey data that reflects perceptions rather than observable decisions. Alm et al. (2015) and Alm and Liu (2017) have conducted a series of laboratory experiments using graduate and undergraduate students in the US as subjects to test this theory and conclude that receiving information on whether one's neighbours are filing returns and/or reporting income has a statistically significant and economically large impact on individual filing and reporting decisions. However, they note that 'neighbour' information does not always improve compliance, as it depends on the content of the information.

These findings suggest information about peers exerts a major influence on tax compliance, but the policy implication is opaque. Information could complicate policy space as some information content reduces tax compliance. For a policymaker interested in improving tax compliance, it is important to unpack how different information contents work and the extent to which information can be strategically employed as an additional tool to improve compliance.

A few recent studies have started probing the conditions under which specific information content could improve tax compliance. Kettle, Hernandez, Ruda and Sanders (2016) conducted a national level randomised evaluation of the effect of social norms on tax compliance in Guatemala. The tax authority sent letters to defaulters with information indicating that the majority of the labour force were already paying tax and encouraging the defaulters to join the status quo. They found a higher payment rate among the treated group relative to the control group. Another large-scale test of social influence theory by the World Bank (2018) in Poland found that behavioural intervention, where defaulters are informed about the number of compliant taxpayers, induces positive responses. In addition, it was observed that compliance is much improved with behavioural letters using hard tones that highlight sanctions for noncompliance.

Lefebvre, Pestieau, Riedl and Villeval (2011) conducted several laboratory experiments in Belgium, France and the Netherlands to delineate between different information contents. In the experiment where subjects were shown bad examples of low compliance, tax evasion tended to increase. They reported no significant effect when subjects were shown good examples of tax compliance. Despite these countries being in a similar development class, significant heterogeneity was found across countries, age group and gender, with males evading more than females. 
There are four key conclusions that can be drawn from the existing literature. First, while social influence and norms are important, they are more effective when targeted around descriptive norms - what other taxpayers do. Second, the context matters as effect size and significant level vary across countries and demographic characteristics. Third, there is a limit to using observational data (survey) in evaluating the effect of social norms; hence experimental methods (field or laboratory) have been crucial in the literature on social influence theory. Fourth, there is a paucity of studies on the social influence theory specific to sub-Saharan African countries. Yet, given that context matters, the applicability of these findings in African settings, and their implications, are still unknown. The trust level, value system and general cultural norms vary widely within the continent (Okoye 2020), which points to the need for evidence drawn from African experiences. In this study, we address some of these concerns based on an artefactual field experiment among own account workers in Nigeria.

\section{Theoretical framework}

We model the role of information about tax behaviour among peers using the extension of the standard economic model proposed by Alm, Bloomquist and McKee (2015). Specifically, Alm, Bloomquist and McKee extended the one-stage tax decision framework of Allingham and Sandmo (1972) to a two-stage decision framework in which the individual first decides whether to file an income tax return or not and if income is filed, decides how much income to report to the tax authority. Alm, Bloomquist and McKee incorporate information about peers into the model as a psychic cost the guilt that is felt by an individual who cheats on his or her tax liability. We build on and extend this model to account for three types of information content: (1) full information about peers' tax behaviour; (2) partial information revealing the highest taxpayers; and (3) partial information revealing only those audited and the penalty paid for under-reporting.

\subsection{The two-stage tax decision framework}

In the first stage, a representative taxpayer who earns a gross income, $Y$, decides whether to file an income tax return or not. Filing is the first step in tax payment as information on gross income and tax obligation are generated at the filing stage. We assume the detection probability for an individual not filing to be $\rho$ and the enforcement penalty imposed on detected non-filers is $\alpha$ share of true income. We consider only proportional tax rate which is given by $t$. If an individual does not file and is not detected, the gross income, $Y$, is retained. However, if the defaulter is caught, both the actual income and the penalty are deducted.

The filing decision is therefore given by:

Filing Decision $=F D=(1-\rho) U(Y)+\rho U(Y-t Y(1+\alpha))$

where $U($.$) captures the utility function of a representative taxpayer.$

At the second stage, those that choose to file are to decide whether to fully report or to under-report their income. We assume the detection probability for under-reporting to be $\theta$ and the enforcement penalty imposed for tax avoidance to be $\mu$. It is expected $\theta$ will be higher than $\rho$ in a highly informal economy given the weak identification system. The penalty for under-reporting, $\mu$, will also differ from the penalty for not filing, $\alpha$. We define the amount of income declared by the taxpayer as $D$, which could be between 0 and the true income. 
The decision to report is therefore given by:

Reporting Decision $=R D=(1-\theta) U(Y-t D)+\theta U(Y-t D-(1+\mu)(Y-D))$

The tax decision on filing and reporting is conditional on parameters in equations (1) and (2). The individual will first decide whether to file a tax return or not by comparing the expected utility from non-filing in equation (1) with the expected utility from filing and reporting described by equation (2). If an individual files a tax return, he or she thereafter must choose the optimal amount of income to report based on equation (2). The model as so far described is similar to the standard economic model with only an extension to the two-stage decision framework.

\subsection{Incorporating the peer effect}

To account for the impact of possible information about peers on tax behaviour, Alm et al. (2015) introduced the concept of a psychic factor based on social norms. The psychic factor is a variable $(\pi>0)$ measuring, in monetary terms, the feeling of guilt that is associated with evading one's own tax liability if one is not caught. We depart from Alm et al.'s approach in characterising the psychic factor. While they conceptualise the psychic factor only as a cost that arises when individuals deviate from social norms of high tax compliance, as literature has shown, a peer effect could also generate low compliance if the majority are defaulting. To extend the psychic factor to a more general tax behaviour, $\pi$ is allowed to take negative value that is $-\infty<\pi<\infty$. A positive $\pi$ translates to psychic costs or feelings of guilt for tax evasion, while a negative $\pi$ translates to a psychic benefit that an individual draws from not complying with the prevailing social norms.

We introduce the psychic factor $(\pi)$ into the representative taxpayer utility function in equations (1) and (2). These extensions yield:

Augmented Filing Decision: $A F D=(1-\rho) U(Y-\pi)+\rho U(Y-t Y(1+\alpha))$

Augmented Reporting Decision:

$A R D=(1-\theta) U(Y-t D-\pi)+\theta U(Y-t D-(1+\mu)(Y-D)$

The decision rule therefore still holds regarding the condition of filing a tax return and reporting optimal income. However, we can now draw some comparative static results about a peer effect and its implication for compliance attitudes. Under the condition that the utility function is concave and monotonically decreasing, the comparative static result for filing is given by:

$\frac{\partial A R D}{\partial \pi}-\frac{\partial A F D}{\partial \pi}=+(1-\rho) U^{\prime}(Y-\pi)-(1-\theta) U^{\prime}(Y-t D-\pi) \gtrless 0$

and the comparative static result for reporting is derived as follows:

$$
\partial A R D / \partial \pi=\pi(1-\theta) U^{\prime}(Y-t D-\pi) \gtrless 0
$$

This implies that an increase in the psychic factor could either increase or decrease the filing rate and amount of reported income, depending on the sign and magnitude of the psychic factor, all other things being equal. Information, when not targeted, can shape compliance levels in different directions. If everyone is exposed to information about whether their peers are filing, how much is paid in tax, the number of people penalised for dishonest filing in the 
group and the penalty paid, this set of information can be interpreted differently by different people. While some might be focused on the penalty and therefore be induced to start filing and reporting their optimal income and paying their tax, others might look at the information about low tax paid by others and also start evading taxes. The uncertainty means the eventual effect of providing full information will have an ambiguous effect on tax compliance. This argument suggests the following proposition on the effects of full information:

Proposition 1: An increase in the psychic factor $\pi$ has an ambiguous effect on the probability of filing a tax return and the amount of reported income.

The implication of this result is that an information intervention, left on its own, cannot guarantee higher tax compliance. This is an observation that is well observed in the literature. However, when the information is specific and targeted, the dynamics could change. Let's assume that potential taxpayers are only shown information about the highest taxpayer in their reference group and nothing else. This is an instance of revealing partial information to encourage compliance. In this case, individuals not filing, or under-reporting, will feel a sense of guilt, as the observed social norms suggest that others within the reference group are tax compliant. Exposing individuals to positive information about the most compliant taxpayer could also create competition to be the ideal taxpayers for others.

This intervention ensures that the psychic factor is within a positive range $(\pi>0)$. This modification changes the direction of the peer effect, as an increase in psychic factor is expected to lead to an unambiguous increase in the amount of reported income. This reasoning suggests the following proposition on the effects of partial information:

Proposition 2: With an intervention exposing information about the highest taxpayers, an increase in the psychic factor, $\pi$, will lead to an increase in the amount of reported income of an individual who files a return, although its effect on the probability of filing a tax return remains ambiguous.

Another intervention that can yield a similar outcome to the one above is when only information about those that are punished is revealed to potential taxpayers. Again, this creates a sense of guilt among those that are not caught. It also acts as a threat about the likely punishment to be faced if caught. This will restrict the psychic factor to within positive range $(\pi>0)$ and lead to higher tax compliance. This analysis implies the following proposition:

Proposition 3: With an intervention exposing information about defaulters only, an increase in the psychic factor, $\pi$, has an ambiguous effect on the probability of filing a tax return. However, this leads to an increase in the amount of reported income of an individual who files a return.

It is equally important to ask how the effect of information and peer effect varies with changes in group size. The peer effect works through descriptive norms rather than injunctive norms (Hallsworth et al. 2017). Descriptive norms are based on what individuals directly observe among their peers, while injunctive norms are based on what individuals think others are doing. In a small group, individuals are more likely to directly observe who the highest taxpayer is or who was audited and incurred a stiff penalty. The descriptive norms are more likely to be replaced with injunctive norms as group size increases. This suggests that peer effect will be stronger among smaller groups than larger groups. This reasoning suggests this proposition on the effects of group size:

Proposition 4: The tax compliance and the role of peer effect varies across group size, with the psychic factor, $\pi$, higher, among small groups than large groups. 


\section{Experimental design}

The study implements an experimental setting which replicates the elements of the voluntary reporting system of Nigeria's individual income tax. Income is earned by performing a computerised task: selecting a number from zero to ten. Afterwards, participants must choose whether to file their tax return or not; if they choose to file, they must choose how much income to report, which can be between zero and the income earned. Taxes are paid on the income reported. However, participants are randomly audited and, in the event that unreported tax is discovered, the individual must pay all unreported tax plus a penalty. The detection probability for not filing is set at zero, which implies that those that do not file their tax return are not likely to be detected. This is a key feature of an informal sector with economic activities operating underground.

Participants were informed of the features of the experimental setting (that is, the tax rate, audit rate, and penalty rate). The process was repeated over ten rounds as each round represents a single tax period. At the end of all rounds, participants are paid in cash as their laboratory earnings are converted to Naira.

The participants were recruited through a combination of online and field visits to low-income areas in Abuja. The researchers set up an online google form to collect basic information on gender, age, and occupation type (formal or informal) from potential participants. The research team thereafter visited various low-income areas in Abuja (Nyanya, Mpape and Dutse) to recruit subjects and assist them in filling in the google form. We also announced the recruitment process on social media. We at no point indicated that only informal sector workers would be recruited. However, only those that were working in establishments not registered were selected. Our working definition of informal sector was firms which are not registered by the Corporate Affairs Commission (CAC) in Nigeria. Some of the participants worked in the formal sector, such as for the National Youth Service Corps (NYSC), but were added to the participant pool if they engaged in other activities in the informal sector. For example, NYSC members that had other vocational activities not officially registered were included in the participant pool. The final participants selected were those that met the participation criteria set: working in the informal sector or being an own account worker. Participants were only exposed to a single treatment.

As soon as participants arrived at the laboratory, they were randomly assigned to a computer station, and to a specific group of five individuals (including the participant) with group members considered as neighbours during the experiment. Each experimental session had at least three groups, which made it hard for anyone to know the actual members of their group. Groups were maintained throughout the experiment and each group was assigned a single treatment for the duration of the experiment. Basic instructions (see Appendix 2) were provided via a hardcopy and were read to participants. The first two rounds were used as test rounds where decisions made were non-scoring. To overcome deficiencies in using computers, each participant was taken through how to use the computer system provided.

During the remainder of the experiment, there was no interaction between participants and the person running the experiment, or between each other. Participants were informed that all responses would be anonymous as the computers used would not be matched with the individual identifiers collected. Participants were also told that payments would be made privately at the end of the experiment. The aim was to eliminate subject-to-subject interaction and subject-to-experimenter interaction.

The first step in the experiment involved performing an earning task that required participants to select a number between zero and ten. The computer also randomly picked a number between the same range. Matching the computer pick earned the participant 1,000 points. 
The least a participant could earn was 500 points for selecting the figure the farthest distance to the computer pick. Participants could decide to file their tax or not by selecting a 'file' or 'not file' button. In the event that the participant selected the 'not file' option, a new round began.

Participants that decided to file were shown details of the experimental parameters.

Specifically, the screen showed the tax rate, audit rate, and penalty rate. Afterwards, the participant had to choose the amount to report to the tax authority. For each set of entries, the computer automatically calculated the tax liability.

The computer randomly selected which participants were to be audited. Each taxpayer was audited independently, and the audit was applied only to the current period's declarations. In the case of under-reporting, the computer automatically deducted the taxes paid and the penalties due. Afterwards, the screen showed the earnings and audit outcome summary for the round.

The features of the experimental setting included a tax rate of 20 per cent, an audit rate of 20 per cent and a penalty rate of 40 per cent (participants had to pay unpaid taxes plus a penalty of 40 per cent of unpaid taxes if audited). These features were maintained throughout the sessions.

The exact duration of the experimental session was not disclosed, and the session was predetermined to last for ten real rounds. A session which included instructions, two practice rounds, and ten real rounds took on average 50 minutes to complete. In total, 212 subjects participated in the experiment. Earnings averaged NGN5,412 (US\$14.2) for subjects. At the end of the sessions, participants completed a short questionnaire in which they reported their age, gender and educational background. Information on prior tax knowledge was also obtained through the questionnaires. Specifically, the participants were asked whether they had paid tax before or not and about their perception of public goods, use of tax revenue and overall governance in Nigeria. Table 1 shows the demographic composition of the participants in the experiment. The majority of the participants (50 per cent) were aged 24 to 29 years, with those aged 18 to 23,30 to 35, and 36 to 41 accounting for 31 per cent, 13 per cent and 4 per cent respectively. Also, 64 per cent of the participants were male.

Table 1 Demographic composition of the participants

\begin{tabular}{|l|l|r|}
\hline \multirow{4}{*}{ Variable } & Category & Percentage \\
\hline \multirow{5}{*}{ Age } & $18-23$ years & 30.99 \\
\cline { 2 - 3 } & $24-29$ years & 50.34 \\
\cline { 2 - 3 } & $30-35$ years & 13.44 \\
\cline { 2 - 3 } & $36-41$ years & 3.78 \\
\cline { 2 - 3 } & 42 years and above & 1.44 \\
\hline \multirow{5}{*}{ Gender } & Male & 63.5 \\
\cline { 2 - 3 } & Female & 36.5 \\
\hline \multirow{5}{*}{ Have you paid tax before? } & Student and employed & 24.43 \\
\cline { 2 - 3 } & Unemployed & 37.23 \\
\cline { 2 - 3 } & Self-employed & 26.45 \\
\cline { 2 - 3 } & Employee & 11.89 \\
\hline & No & 46.23 \\
\cline { 2 - 3 } & Yes & 53.77 \\
\hline
\end{tabular}




\subsection{Experimental treatments}

At the end of each round, participants are shown information about the tax behaviour of members of the group. There are three treatments tested in the experiment (see Table 2).

(i) Partial information treatment with example of punishment (T1): all group members are informed of the results of the penalties (unpaid tax plus penalty) for tax evasion of neighbours that have been audited to illustrate the level of compliance among neighbours.

(ii) Partial information treatment with example of good behaviour (T2): after all participants have made their filing decision, the computer informs all group members of the highest taxpayer in their group to indicate compliance.

(iii) Full information treatment (T3): this displays information to group members about whether their peers are filing a tax return, how much is being paid in taxes, the number of people penalised for under-reporting and the penalty paid.

To establish a baseline, we also have a control treatment in which no information on the other members is provided.

Table 2 Experimental treatments

\begin{tabular}{|c|c|c|}
\hline $\begin{array}{c}\text { Penalty information about } \\
\text { neighbours }\end{array}$ & \multicolumn{2}{|c|}{ Tax information about neighbours } \\
\cline { 2 - 3 } & Yes & No \\
\hline Yes & T3 & T1 \\
\hline No & T2 & Control \\
\hline
\end{tabular}

Each treatment including the control group is replicated at least seven times. We also add a treatment in which group size is reduced to three members. This is to test proposition 4 on the effect of group size on level of compliance. Overall, the experiment is programmed using the Zurich toolbox for ready-made economic experiments (z-Tree) developed by Fischbacher (2007).

\subsection{Empirical method}

The experimental data derived was analysed using an econometric model that allows for the estimation of the treatment effects at the individual level while accounting for other confounding variables. Specifically:

$Y_{i, t}=\beta_{1}+\beta_{2} I_{i, t}+\beta_{3} W_{i, t}+\beta_{5} G_{t}+\beta_{6}$ Treatment $_{t}+\beta_{7} X_{i}+\varepsilon_{i, t} \ldots . .(7)$

Where the dependent variable $Y_{i, t}$ is the participant's filing or reporting decision in period $\mathrm{t}$; $I_{i, t}$ is the participant's earned income in period $\mathrm{t} ; W_{i, t}$ is profit earned, that is, income accumulated from the previous rounds in period $\mathrm{t} ; G_{t}$ is a dummy variable for group size; Treatment $_{t}$ denotes the vector of treatment variables, with T3 used as the reference group; $X_{i}$ is a vector of demographic variables (such as participant's age and sex) and other control variables; and $\varepsilon_{i, t}$ is the error term.

The model is estimated for each decision taken by participants, that is, 'filing rate' ( $Y_{i, t}$ is 1 if the tax form is filed, and zero otherwise), and for participants who file a form, their 'reporting rate' $-Y_{i, t}=$ [taxes paid/taxes owed]. The unit of analysis is the individual subject.

Considering that there were several iterations (ten rounds), the dataset is panel. The filing equation was estimated using a linear probability model, while the reporting equation was estimated with a random-effects Tobit model. 


\section{Empirical results}

\subsection{Descriptive analysis}

The study focuses on two aspects of compliance: the filing rate, that is, the share of subjects in a treatment group that files an income tax return in a specific period, and the reporting rate, that is, the average share of income reported across observations in a treatment (taxes paid/taxes owed).

Full compliance occurs when participants file their tax return and report their actual income for each period. At the tax rate of 20 per cent, full compliance is represented by the thick blue line in Figure 3. However, none of the treatments achieve full compliance. On average, T1 and T2 (partial information treatment) have the highest compliance level, and the least compliance is associated with T3. In fact, the control group where no information is revealed about peers has a higher compliance level than T3.

\section{Figure 3 Tax compliance rate among participants over ten rounds}

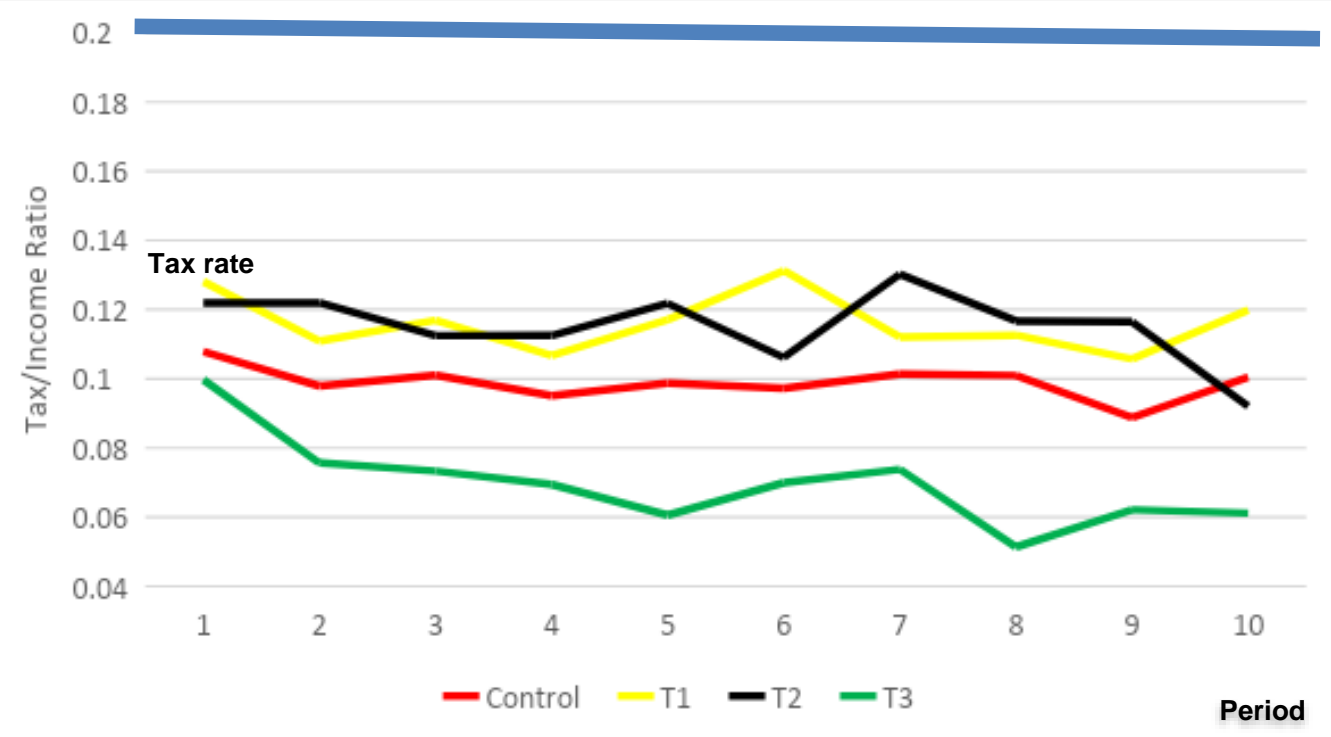

Specific to filing and reporting rates, none of the treatments achieve the optimal level of 100 per cent compliance. Again, the filing rate (Figure 4) and the reporting rate (Figure 5) are higher in T1 and T2 than in the control group and T3. Despite the probability of detection for not filing being zero, a significant number of participants still file their tax return. This contradicts the prediction of the standard economic model of zero compliance when the deterrence mechanism is absent. That the compliance level is above zero serves as justification for the social influence theory and other theories around tax morale. One caveat to this argument is if participants believe their actions are being observed. However, the difference observed under different information interventions demonstrates that such caveat did not hold. The conclusion that can be drawn is that providing specific information (only regarding those penalised or those who have been compliant citizens) yields better results than providing blanket information. 


\section{Figure 4 Filing rate among participants}

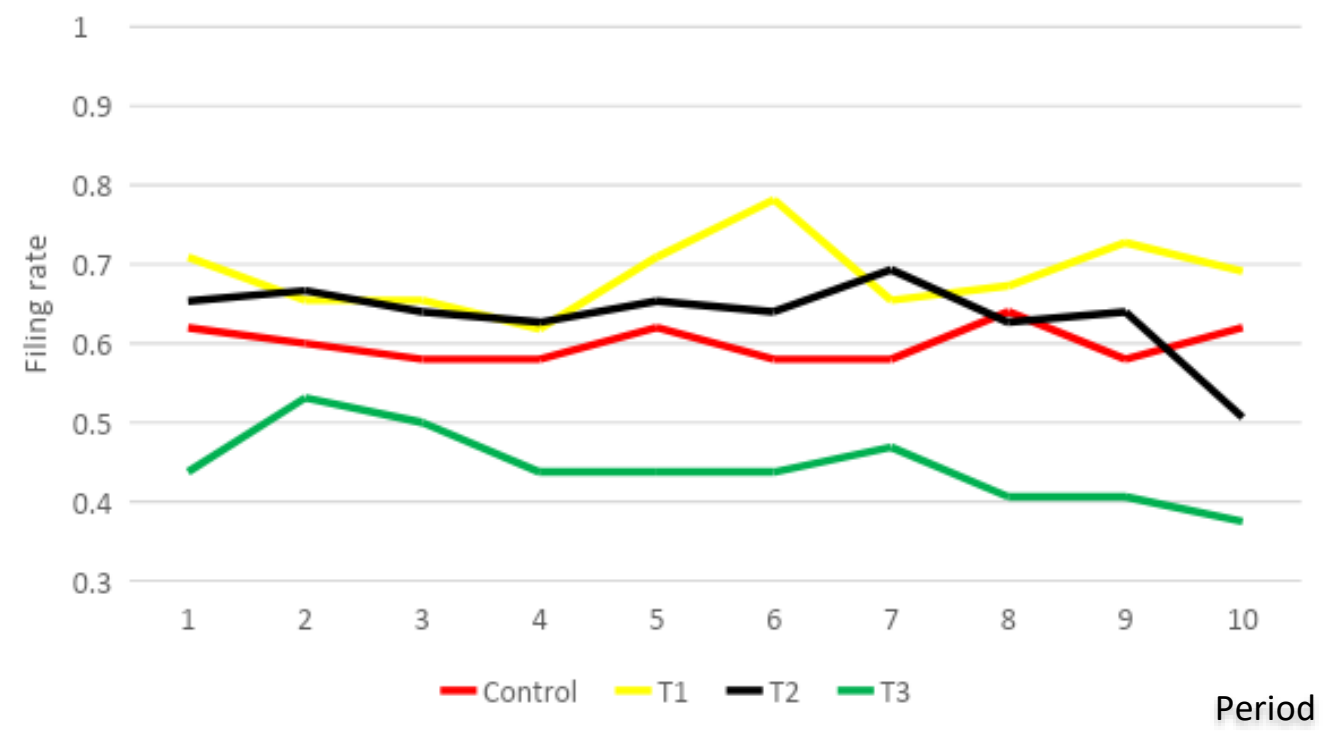

Figure 5 Reporting rate among participants

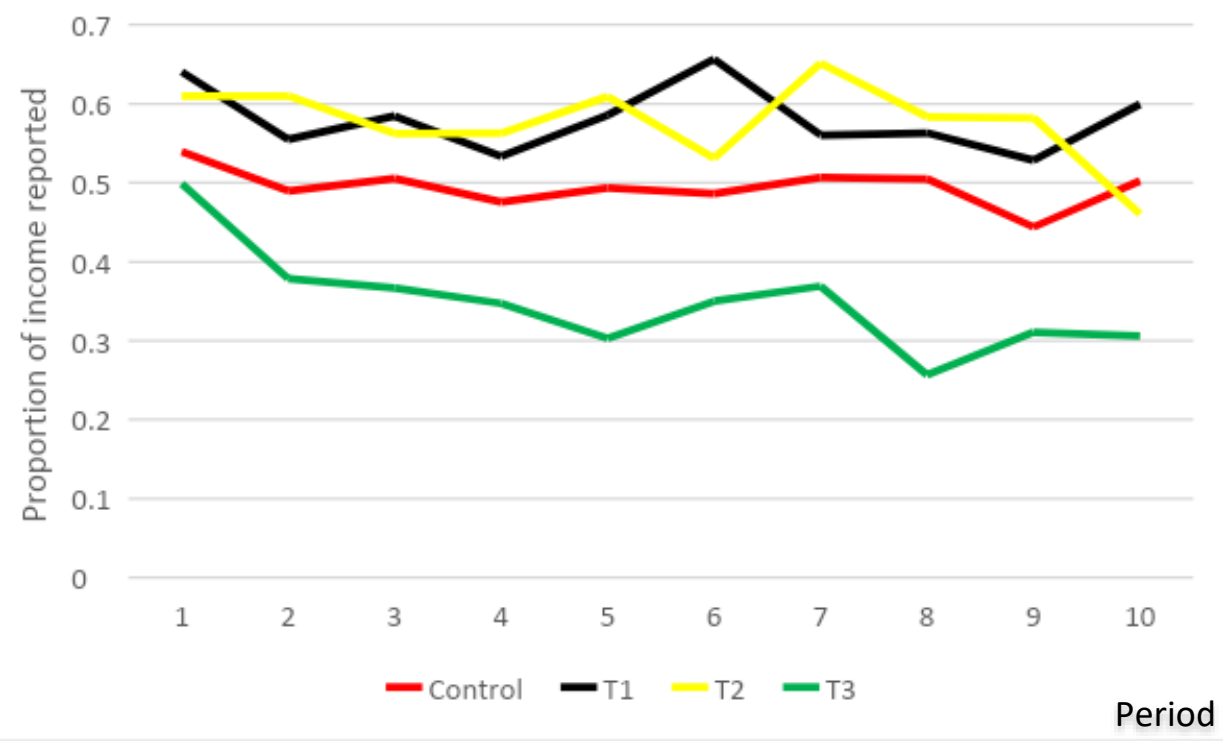

\subsection{Regression results}

The descriptive analysis is not robust as it fails to account for the possible effect of demographic factors and other confounding variables. We go further in using a multiple regression model to account for key demographic and behavioural variables among participants. Estimation results are presented in Table 3 . In line with the descriptive results, the behaviour of a participant's neighbours has a statistically significant and large effect in increasing both filing of tax returns and reporting of true income. Participants who were provided with information on the tax paid by the highest income earners in their group were 21 per cent more likely to file their tax return and 23 per cent more likely to file their actual income relative to those who had been shown full information sets. Similarly, participants who were provided with information on the penalty paid by tax evaders in their group were 16 per cent more likely to file their tax return and 23 per cent more likely to file their actual income relative to those who had been shown full information sets. Essentially, providing information on good and bad practices yields better tax compliance than settings with full 
information and no information. Further comparison across treatments also shows that the compliance level was significantly higher under T1 and T2 than in the control group.

T3 yielded sub-optimal outcomes, both in terms of the filing rate and the reporting rate. Under T3, the participants were exposed to full information which generated two counteracting effects. The exposure to information about those paying and the penalty for tax avoidance will incentivise a positive response to improve compliance like the instance of T1 and T2. However, knowing that the majority could evade taxes yet not be punished discourages tax compliance. While these two effects are present, the results indicate a higher and dominant effect of the negative response.

With the inclusion of control variables (age, gender, income, group size, total profit, and penalty paid), the effectiveness of the partial information over the full information treatment is mostly confirmed, except the reporting rate for T2, which is now insignificant. As such, participants who have been provided with information on the tax paid by the highest income earners in their group are 15 per cent more likely to file their tax return, and those who have been shown information on the penalty paid by tax evaders in their group are 11 per cent more likely to file their tax return.

We found no significant difference between T1, T2 and the control group after accounting for the covariates. The effect of group size is not consistent across tax processing stages. While the filing rate is significantly higher among those in the larger group, we found the opposite but insignificant effect on the reporting rate. This implies group size, at least within the limited scope of the experiment, plays a weaker role in tax compliance. Put differently, the threshold for the peer effect to be dampened by group size is likely much larger than we accounted for in the experiment.

Higher earnings per period increases the likelihood of filing tax returns and reporting the true income; higher profit (accumulated earnings) and paying a penalty in the past have a negative effect on tax compliance. Lower earnings could reduce the incentive to file or report truthfully as paying tax will further reduce the income. However, those that have accumulated wealth may have identified loopholes in the system that enable tax evasion such as the low probability of being audited if an individual does not file their tax returns. Similarly, the negative impact on tax compliance from having an audit experience can also be from having knowledge of tax evaders who were not penalised. Middle-aged adults (36 to 41 ) are also more likely to be tax compliant relative to young adults (18 to 24) which can be attributed to the fact that social norms and psychic costs are higher among older people.

Regarding proposition 1, we found that the negative effect of information about peers' tax behaviour dominates the positive effect. The effect of full information is not ambiguous, but sub-optimal compared to other information contents. The findings, however, support propositions 2 and 3 on the effect of partial information in improving tax compliance. Targeted information could serve as a useful non-pecuniary tool to enhance tax compliance. Also, we do not find a robust effect of group size as indicated under proposition 4. 
Table 3 Main regression results

\begin{tabular}{|c|c|c|c|c|}
\hline & $\begin{array}{l}(1) \\
\text { Filing rate }\end{array}$ & $\begin{array}{c}(2) \\
\text { Reporting rate }\end{array}$ & $\begin{array}{c}(3) \\
\text { Filing rate }\end{array}$ & $\begin{array}{c}(4) \\
\text { Reporting rate }\end{array}$ \\
\hline \multicolumn{5}{|l|}{ Treatment } \\
\hline Control & $\begin{array}{c}0.129^{* * *} \\
(0.0345)\end{array}$ & $\begin{array}{l}0.146^{* * *} \\
(0.0345)\end{array}$ & $\begin{array}{c}0.125^{* * *} \\
(0.0331)\end{array}$ & $\begin{array}{l}0.0538^{*} \\
(0.0303)\end{array}$ \\
\hline Treatment 1 & $\begin{array}{l}0.210^{* * t} \\
(0.0339)\end{array}$ & $\begin{array}{c}0.232^{* * *} \\
(0.0339)\end{array}$ & $\begin{array}{l}0.148^{*+* t} \\
(0.0325)\end{array}$ & $\begin{array}{c}0.0278 \\
(0.0302)\end{array}$ \\
\hline Treatment 2 & $\begin{array}{l}0.161^{* * t} \\
(0.0322)\end{array}$ & $\begin{array}{l}0.228^{* * t} \\
(0.0322)\end{array}$ & $\begin{array}{l}0.107^{*+*} \\
(0.0311)\end{array}$ & $\begin{array}{l}0.0717^{* *} \\
(0.0285)\end{array}$ \\
\hline Large group & & & $\begin{array}{l}0.0967^{+* t} \\
(0.0233)\end{array}$ & $\begin{array}{l}-0.0344 \\
(0.0219)\end{array}$ \\
\hline Income & & & $\begin{array}{c}0.000151^{*} \\
(0.0000879)\end{array}$ & $\begin{array}{l}0.000175^{* *} \\
(0.0000795)\end{array}$ \\
\hline Total profit & & & $\begin{array}{l}-0.0000596^{*+*} \\
(0.00000802)\end{array}$ & $\begin{array}{l}-0.0000575^{t+*} \\
(0.00000730)\end{array}$ \\
\hline Penalty paid & & & $\begin{array}{l}-0.353^{* * *} \\
(0.0292)\end{array}$ & $\begin{array}{l}-0.406^{* * *} \\
(0.0265)\end{array}$ \\
\hline \multicolumn{5}{|l|}{ Age group } \\
\hline 24-29 years & & & $\begin{array}{l}-0.0535^{* *} \\
(0.0231)\end{array}$ & $\begin{array}{l}-0.00538 \\
(0.0210)\end{array}$ \\
\hline 30-35 years & & & $\begin{array}{l}-0.0404 \\
(0.0325)\end{array}$ & $\begin{array}{l}-0.0645^{t^{*}} \\
(0.0295)\end{array}$ \\
\hline $36-41$ years & & & $\begin{array}{l}0.166^{* * *} \\
(0.0540)\end{array}$ & $\begin{array}{c}0.132^{* * *} \\
(0.0489)\end{array}$ \\
\hline 42 years and above & & & $\begin{array}{l}-0.0416 \\
(0.0869)\end{array}$ & $\begin{array}{c}-0.129 \\
(0.0787)\end{array}$ \\
\hline Male & & & $\begin{array}{c}0.0265 \\
(0.0215)\end{array}$ & $\begin{array}{l}0.0372^{*} \\
(0.0195)\end{array}$ \\
\hline Filing rate & & & & $\begin{array}{c}0.677^{+* * *} \\
(0.0378)\end{array}$ \\
\hline Constant & $\begin{array}{c}0.475^{\star \star *} \\
(0.0269)\end{array}$ & $\begin{array}{c}0.349^{\star * \star} \\
(0.0270)\end{array}$ & $\begin{array}{c}0.477^{\star \star \star} \\
(0.0874)\end{array}$ & $\begin{array}{c}0.0298 \\
(0.0812) \\
\end{array}$ \\
\hline Control vs T1 & $7.48^{* * *}$ & $8.30^{* * *}$ & 0.61 & 0.98 \\
\hline Control vs T2 & 1.32 & $8.55^{* * *}$ & 0.49 & 0.56 \\
\hline
\end{tabular}

Standard errors in parentheses; * $p<0.1,{ }^{* *} p<0.05,{ }^{* * *} p<0.01$; notes: The dependent variables are filing $(=1$ if yes, 0 if otherwise) and reporting rate (=taxes paid/taxes owed).

\subsection{Effect of tax knowledge and governance}

After each experimental session, participants completed a questionnaire that assessed their prior tax knowledge and their perception of governance in Nigeria. As argued by Besley and Persson (2014), high corruption may hinder the emergence of social norms of compliance. Lack of knowledge about tax rules can influence the taxpayers' perceptions of the size of the tax burden and the unfairness of the tax system and this could result in low compliance (Mascagni and Santoro 2018). In addition, if previous experience with the tax system is that of unfairness, then tax knowledge could have a negative effect on compliance. We account for these factors in the regression result presented in Table 4.

The findings show that those that have paid their tax before are 4 per cent less likely to file their tax return relative to those without prior experience. We also found a negative but insignificant effect of tax knowledge on reporting rate. Similarly, there is no significant difference in the tax behaviour between those that perceive government as either good or bad. However, those that are indifferent about the level of governance are less likely to file their tax and report their true income respectively, relative to those that believe that the level of governance is poor. Overall, we found tax knowledge and perception of governance as playing a minimal or negative role for tax compliance. 
Table 4 Regression results accounting for governance and tax knowledge

\begin{tabular}{|c|c|c|}
\hline & $\begin{array}{c}(1) \\
\text { Filing rate }\end{array}$ & $\begin{array}{c}(2) \\
\text { Reporting rate }\end{array}$ \\
\hline \multicolumn{3}{|l|}{ Treatment } \\
\hline Control & $\begin{array}{c}0.113^{* * *} \\
(0.0336)\end{array}$ & $\begin{array}{c}0.0493 \\
(0.0310)\end{array}$ \\
\hline Treatment 1 & $\begin{array}{l}0.148^{*+t} \\
(0.0325)\end{array}$ & $\begin{array}{l}0.0243 \\
(0.0304)\end{array}$ \\
\hline Treatment 2 & $\begin{array}{c}0.103^{* * t} \\
(0.0313)\end{array}$ & $\begin{array}{l}0.0657^{* *} \\
(0.0289)\end{array}$ \\
\hline Large group & $\begin{array}{l}0.0955^{*+*} \\
(0.0233)\end{array}$ & $\begin{array}{l}-0.0313 \\
(0.0219)\end{array}$ \\
\hline Income & $\begin{array}{c}0.000143 \\
(0.0000876)\end{array}$ & $\begin{array}{l}0.000175^{* *} \\
(0.0000795)\end{array}$ \\
\hline Total profit & $\begin{array}{l}-0.0000573^{*+*} \\
(0.00000803)\end{array}$ & $\begin{array}{l}-0.0000553^{* * *} \\
(0.00000733)\end{array}$ \\
\hline Penalty paid & $\begin{array}{l}-0.352^{* * *} \\
(0.0292)\end{array}$ & $\begin{array}{l}-0.404^{* \star *} \\
(0.0267)\end{array}$ \\
\hline \multicolumn{3}{|l|}{ Age group } \\
\hline 24-29 years & $\begin{array}{l}-0.0427^{*} \\
(0.0233)\end{array}$ & $\begin{array}{l}-0.00146 \\
(0.0212)\end{array}$ \\
\hline 30-35 years & $\begin{array}{l}-0.0180 \\
(0.0332)\end{array}$ & $\begin{array}{l}-0.0544^{*} \\
(0.0302)\end{array}$ \\
\hline 36-41 years & $\begin{array}{l}0.202^{*+t^{\prime}} \\
(0.0544)\end{array}$ & $\begin{array}{l}0.148^{*+1} \\
(0.0495)\end{array}$ \\
\hline 42 years and above & $\begin{array}{l}-0.0568 \\
(0.0869)\end{array}$ & $\begin{array}{l}-0.147^{\star} \\
(0.0789)\end{array}$ \\
\hline Male & $\begin{array}{l}0.0415^{*} \\
(0.0218)\end{array}$ & $\begin{array}{l}0.0437^{* *} \\
(0.0198)\end{array}$ \\
\hline \multicolumn{3}{|c|}{$\begin{array}{l}\text { Have you paid tax before (reference } \\
\text { group: no) }\end{array}$} \\
\hline Yes & $\begin{array}{l}-0.0411^{* *} \\
(0.0209)\end{array}$ & $\begin{array}{l}-0.0253 \\
(0.0191)\end{array}$ \\
\hline \multicolumn{3}{|c|}{$\begin{array}{l}\text { Perception of governance } \\
\text { (reference aroup }\end{array}$} \\
\hline Indifferent & $\begin{array}{l}-0.0899^{* * *} \\
(0.0302)\end{array}$ & $\begin{array}{l}-0.0779^{* * *} \\
(0.0274)\end{array}$ \\
\hline Good & $\begin{array}{c}0.0325 \\
(0.0215)\end{array}$ & $\begin{array}{l}-0.00786 \\
(0.0195)\end{array}$ \\
\hline Filing rate & & $\begin{array}{l}0.676^{*+t} \\
(0.0380)\end{array}$ \\
\hline Constant & $\begin{array}{c}0.492^{* * *} \\
(0.0882)\end{array}$ & $\begin{array}{c}0.0538 \\
(0.0822)\end{array}$ \\
\hline
\end{tabular}

Standard errors in parentheses; ${ }^{*} p<0.1,{ }^{* *} p<0.05,{ }^{* * *} p<0.01$; notes: the dependent variables are form filed $(=1$ if yes, 0 if otherwise) and reporting rate (=taxes paid/taxes owed).

\section{Policy implications}

This paper examines the role of exposing information about peers' tax behaviour on tax compliance in Nigeria. Based on an artefactual field experiment among own account workers, we find that an information intervention can play an important role in tax compliance. Specifically, targeting information around descriptive norms, what people can directly observe, can be a way to improve tax compliance. Providing information on punishment or good practice, that appeals to feelings of morality, yields higher tax compliance. The findings of the study, that the presence of social norms influences individual behaviour, is consistent with a range of psychological phenomena including bandwagon effects, inclusion in social networks and building social capital, as well as the fear of alienation (Monteiro 2018). Essentially, individuals do not only take into account the financial implications of their decisions but also base their decisions on the social context where decisions are made. However, the results also point to the need to be strategic in the use of information and social influence as this can draw both negative and positive responses. This result underscores exploring only information contexts and types (like T1 and T2 in this study) which have a positive effect on tax compliance. 
Tax enforcement agencies could leverage on positive social influences to develop a social norm of compliance among citizens. However, the more important question is how this social norm emerges. Tax education and perceptions about the level of effectiveness of government are two crucial factors moulding social norms over time. Yet, the study finds that tax knowledge and perception of governance play a minimal or negative role for tax compliance. This points to an important area that policymakers can use to galvanise compliance. The perceived fairness of the tax system and the ability of taxpayers to relate to the effectiveness of use of tax revenue can develop a culture of compliance and, through social interaction, influence others to also pay. In essence, tax compliance is driven by multiple factors, including economic and non-pecuniary factors. The policy agenda should therefore find an optimal policy mix that engenders voluntary compliance. 


\section{Appendices}

\section{Appendix 1}

\section{Summary statistics}

\begin{tabular}{|l|l|l|l|l|l|}
\hline & Overall sample & Control & Treatment 1 & Treatment 2 & Treatment 3 \\
\hline Tax level & $88.92(84.66)$ & $83.53(84.18)$ & $99.160(83.540)$ & $97.55(84.54)$ & $59.51(80.41)$ \\
\hline $\begin{array}{l}\text { Tax to declared } \\
\text { income ratio }\end{array}$ & $0.10(0.09)$ & $0.09(0.09)$ & $0.11(0.09)$ & $0.11(0.09)$ & $0.06(0.09)$ \\
\hline Reported income & $0.52(0.48)$ & $0.49(0.49)$ & $0.58(0.47)$ & $0.57(0.48)$ & $0.34(0.46)$ \\
\hline Final income & $745.57(134.96)$ & $751.96(132.12)$ & $733.35(133.35)$ & $739.52(136.22)$ & $770.77(135.90)$ \\
\hline Filing rate & $0.61(0.26)$ & $0.60(0.32)$ & $0.68(0.26)$ & $0.63(0.18)$ & $0.47(0.24)$ \\
\hline Under-reporting rate & $0.48(0.49)$ & $0.46(0.49)$ & $0.53(0.49)$ & $0.55(0.49)$ & $0.29(0.45)$ \\
\hline Penalty & $45.21(115.58)$ & $52.2(124.29)$ & $39.30(107.70)$ & $37.68(107.21)$ & $62.12(130.64)$ \\
\hline Observation & 2,120 & 500 & 550 & 750 & 320 \\
\hline
\end{tabular}

Note: Standard errors are in parentheses.

\section{Appendix 2}

\section{Instructions for the control group ${ }^{5}$}

Welcome to the experiment. Please remain silent and seated until the end of the experiment. If you have questions at any stage of the experiment, you can only do so by raising your hand and the laboratory assistant will attend to you accordingly. You will now participate in a decision-making experiment that will last several decision 'rounds'.

What material do you have for the experiment? You have been given three tools to make use of during the experiment. First is the computer monitor where you input all your decisions in each round. The second tool is the instruction manual and you are free to read this at any time during the course of the experiment. We have also provided you with a plain sheet to record the income you earned in each round as this information might be required in the course of the experiment.

\section{General instructions}

- In each round, you first complete an earnings task and then make a tax reporting decision.

- Each round is completely independent from the others, which means your decisions in one round in no way affect the outcome of any other round.

- Each of you is a member of a five-person group. The computer managing the experiment completely did the matching of the group, therefore there is no way you can determine the members of your group.

\section{How will you earn income in each round?}

The computer program will select a number between zero and ten. You are then asked to make a guess to predict the number the computer has picked. The closer your prediction is to the number selected by the computer the higher your income. For example, if you pick the same number as the computer, you get 1,000 points; however, the farthest prediction from the number selected by the computer earns just 500 points.

At the end of the experiment, you will exchange:

$5 \quad$ The instruction sets for other treatments are available upon request. 


$$
1,000 \text { points }=\text { N350 }
$$

\section{How does the tax process work?}

This stage involves making a decision about filing and reporting of your income for tax purposes.

- First, you are to choose whether or not to file your tax.

If you file your tax...

- You decide how much income to report bearing in mind that you can choose any amount between zero and the income earned for the round. (Note: income earned is known to only you).

- After reporting your earnings, you are taxed 20 per cent of your declared income. Your income after tax will be the difference between your earned income and tax paid.

- However, you have a chance of being audited. The chance of an audit is 20 per cent, meaning one out of five people will be audited. Audits are determined completely at random and do not depend on your decisions or the decisions of others.

- If you are audited and your declared income is below your actual income, you will be required to pay a penalty equal to 40 per cent of your income for the round.

If you do not file a tax form...

- The chance of being audited is zero. 
Appendix 3 z-Tree interface for the experiment

Earning stage: here the participant makes a guess of a number between 0 and 10 .

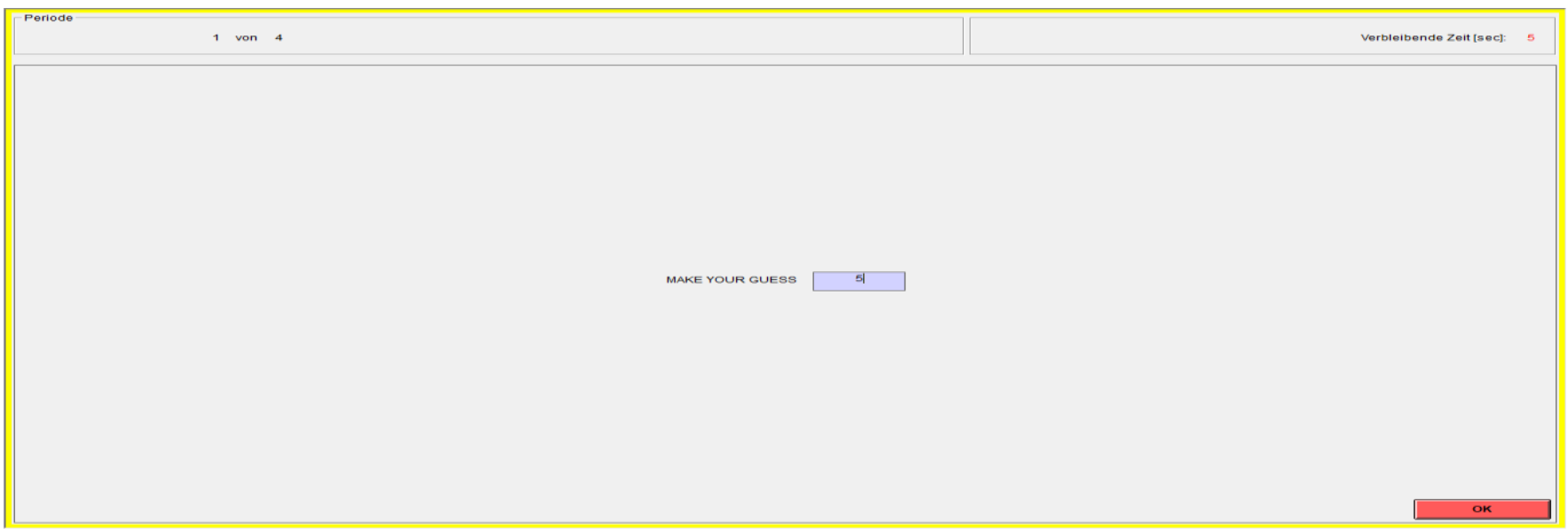

This page displays earnings based on the number guessed.

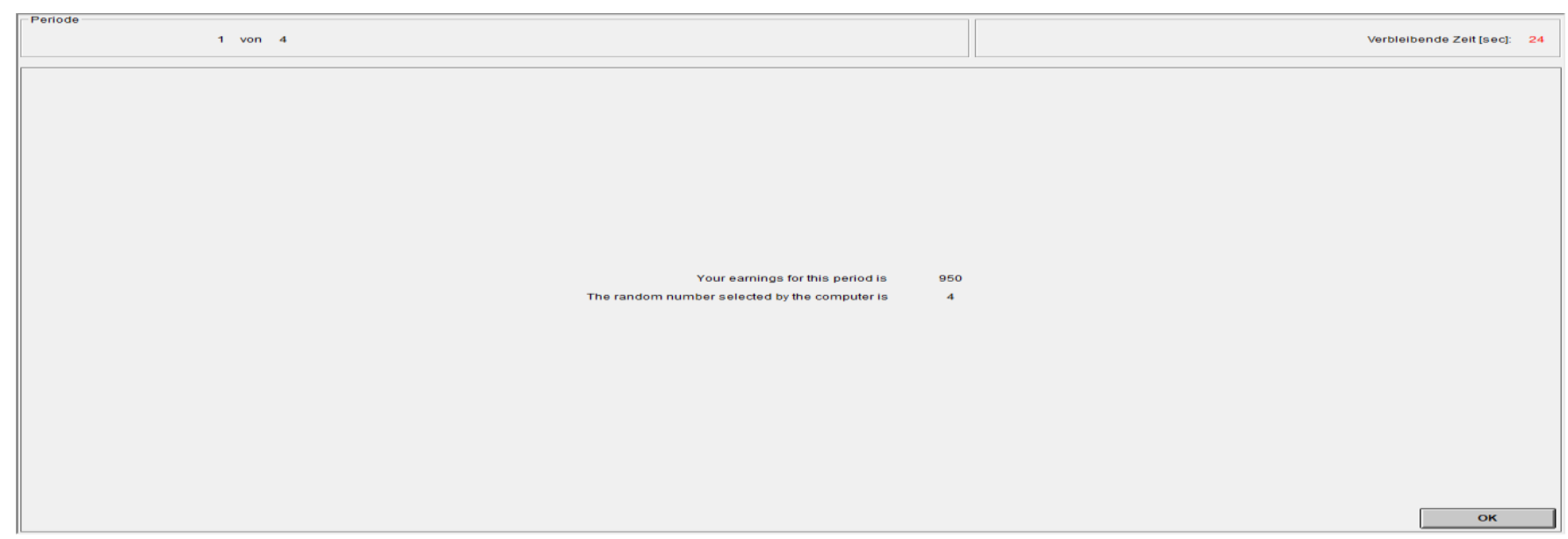

Filing stage: this page asks if you want to file your earnings or not.

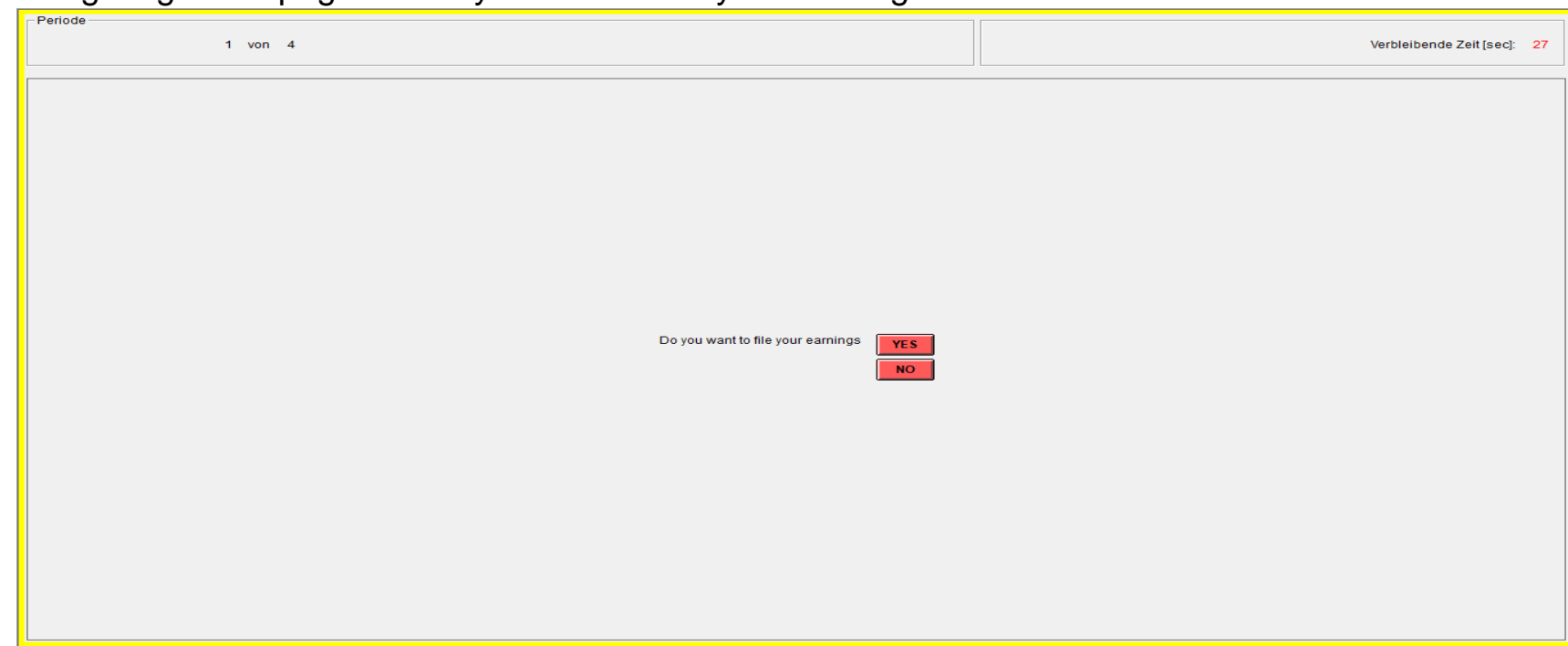


Those filing proceed to the reporting stage. This page displays the experimental parameters: the probability of being audited if you choose to file your income.

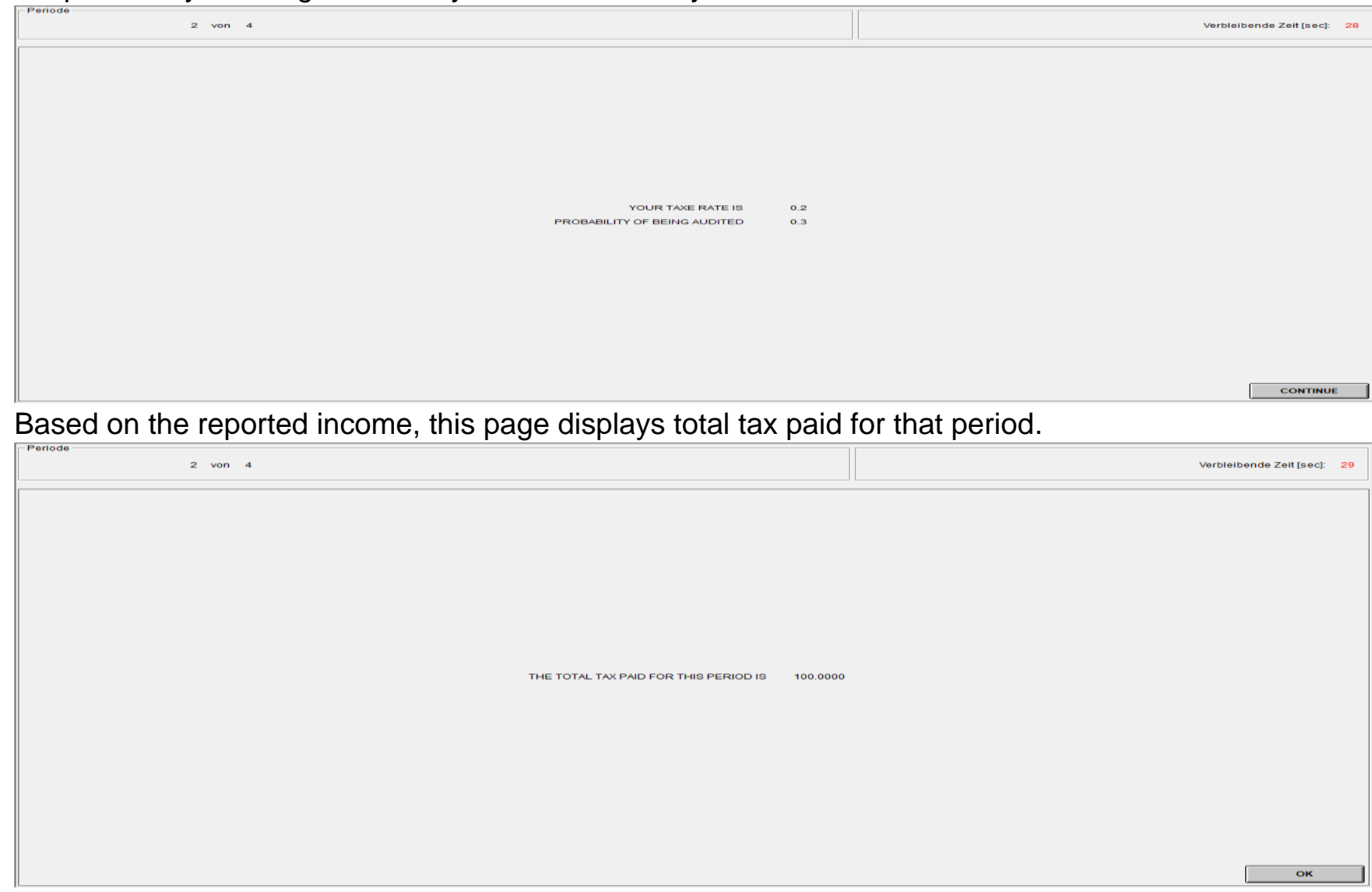

Audit stage: this page is displayed if audited.

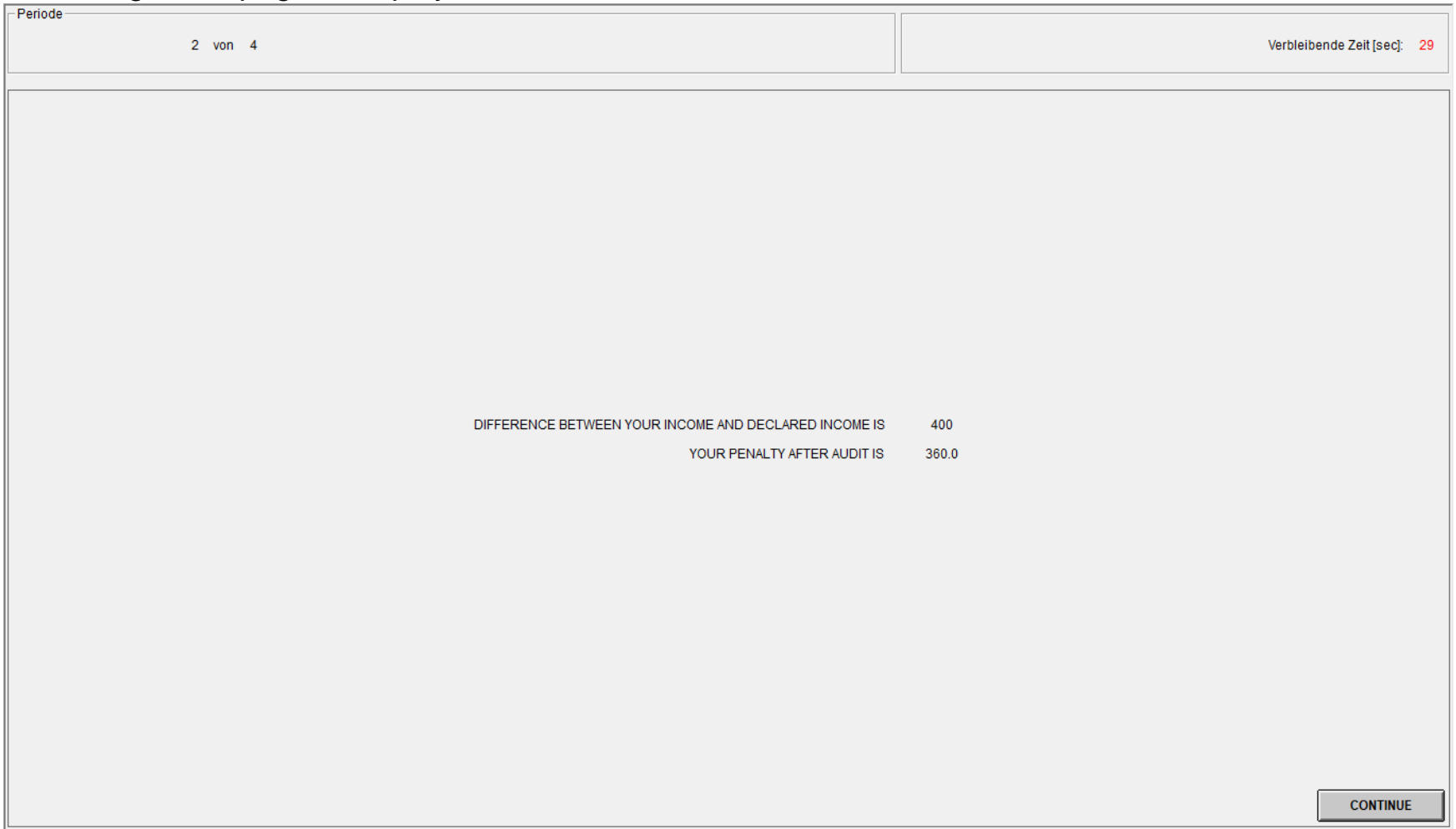


Information stage: for the control group, no information about other participants is shown.

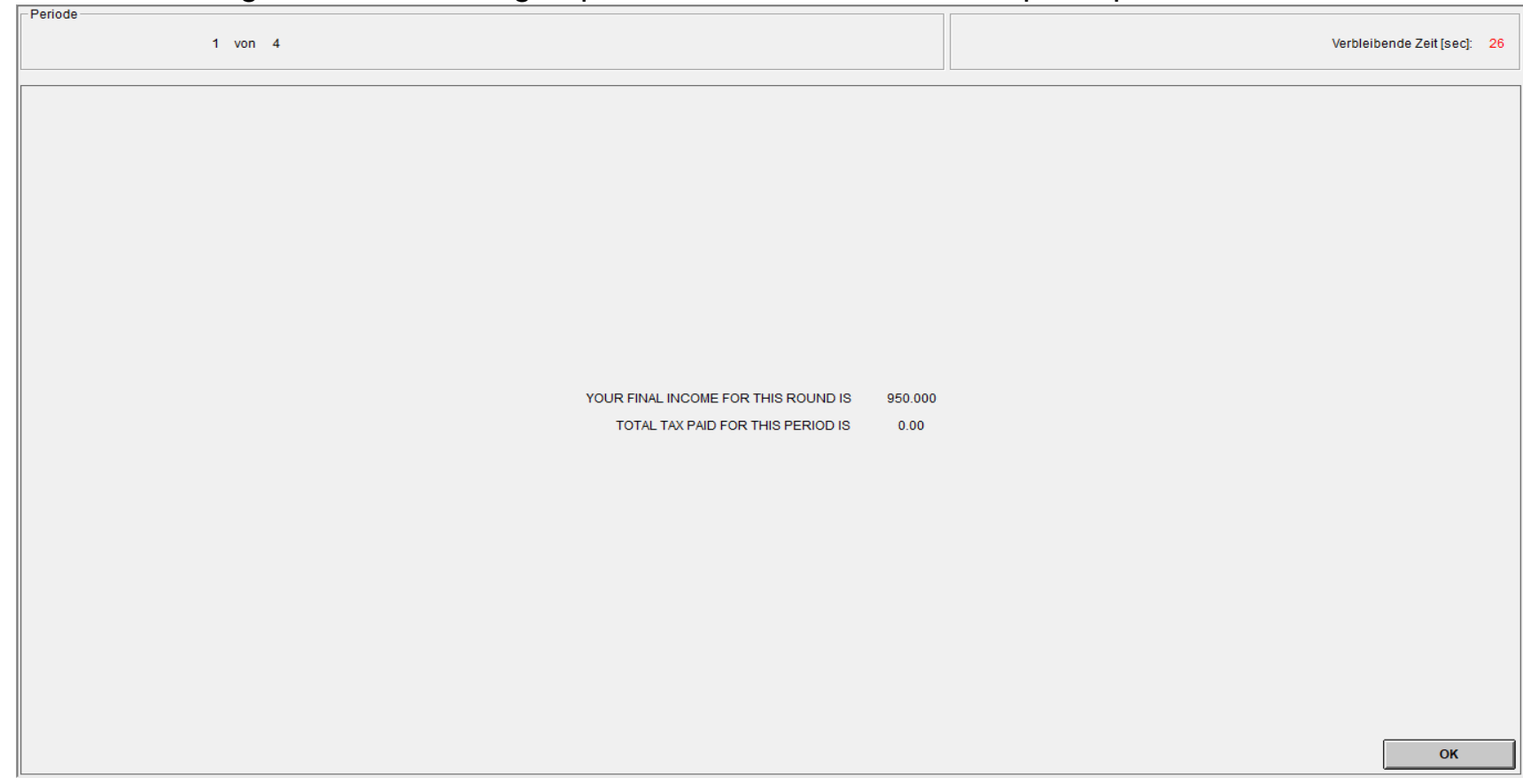

Information stage: for treatment 1, the information page displays the highest taxpayer in your group.

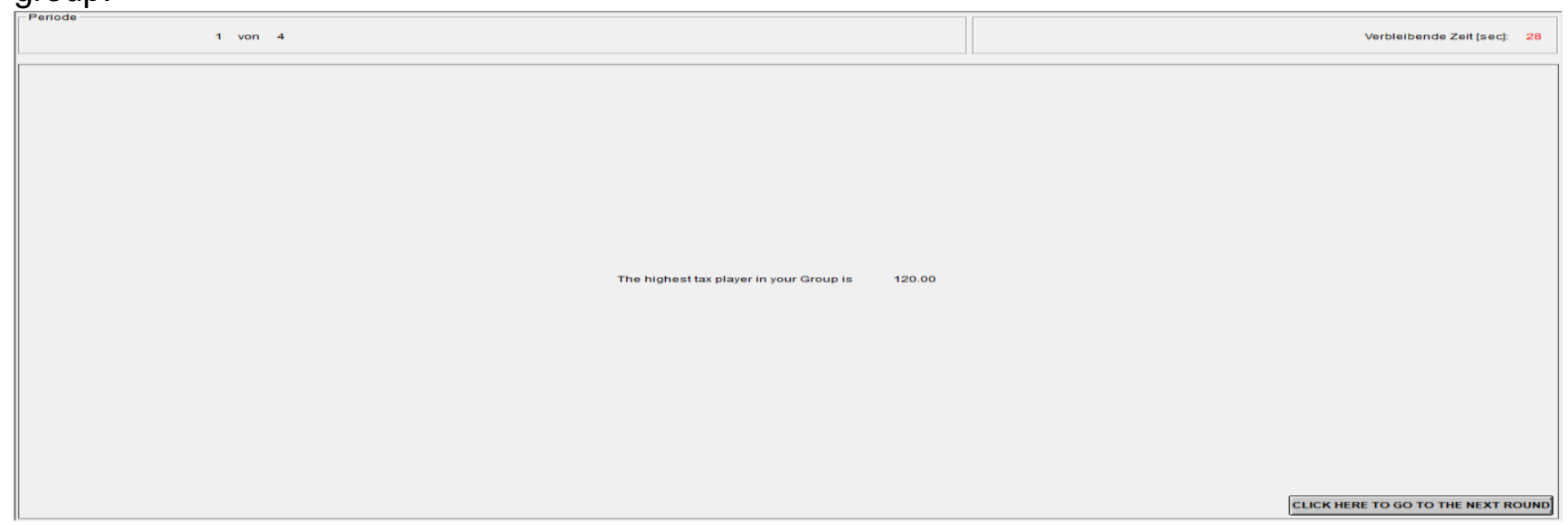


Information stage: for treatment 2, the information page displays the person audited in the group and the amount of penalty paid.

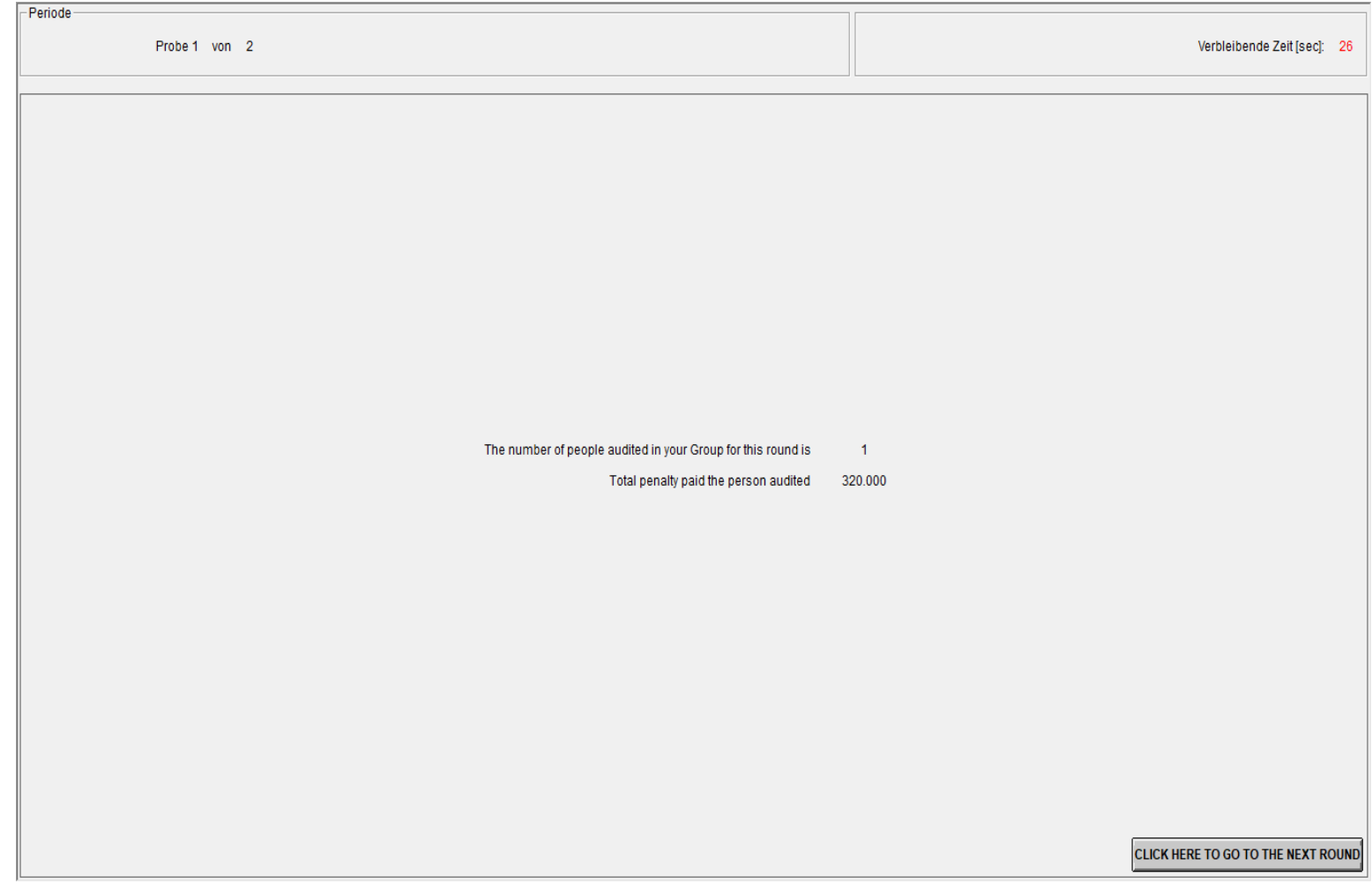

Information display in treatment 3: full information about peers.

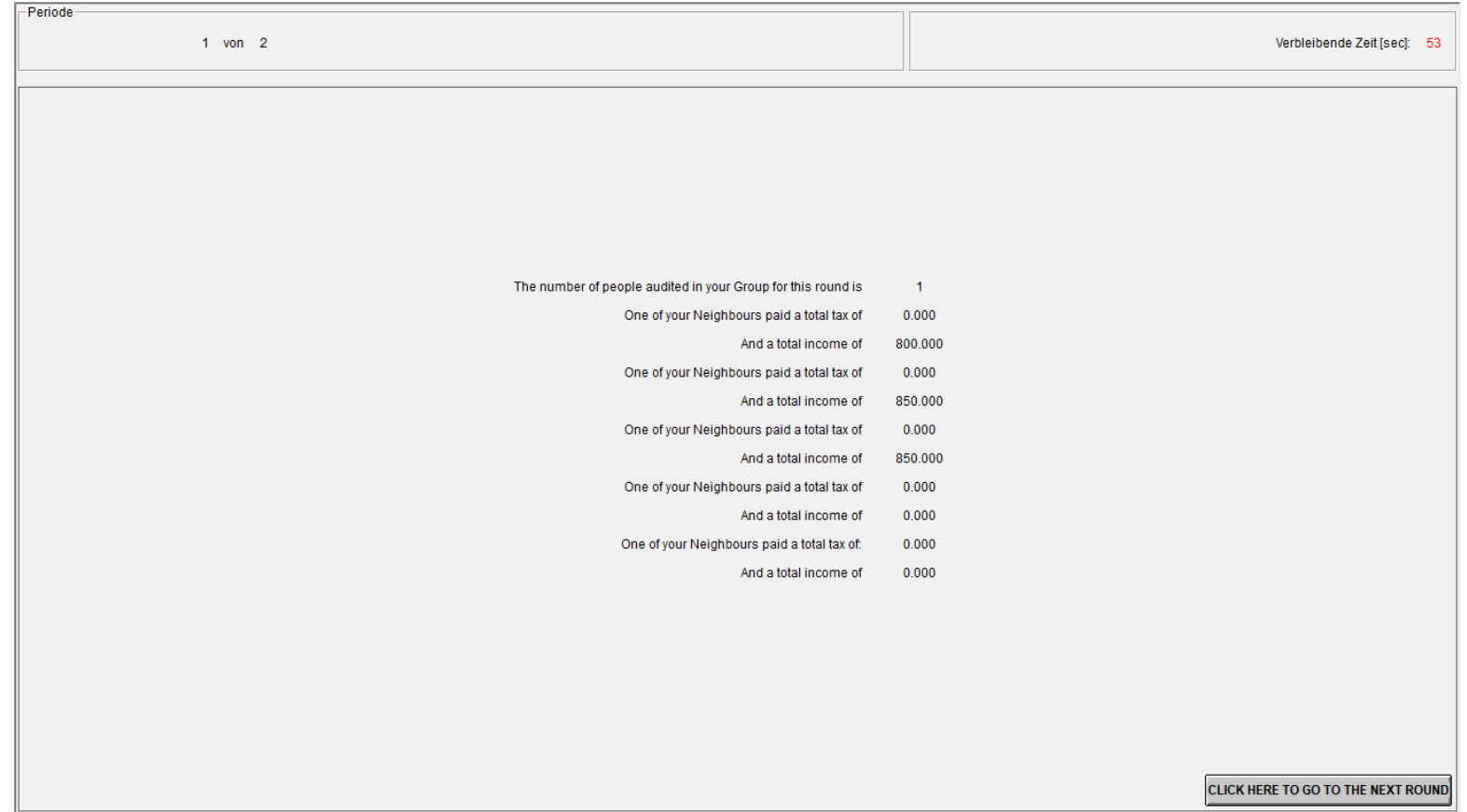




\section{References}

Adeyemi, A. and Adeduro, A. (2020) 'INSIGHT: Tax Revenue Mobilization in Nigeria', Bloomberg Tax, 1 July, https://news.bloombergtax.com/daily-tax-reportinternational/insight-tax-revenue-mobilization-in-nigeria

Ali, M., Fjeldstad, O. H. and Sjursen, I. H. (2014) 'To Pay or Not to Pay? Citizens' Attitudes toward Taxation in Kenya, Tanzania, Uganda, and South Africa', World Development 64: 828-842

Allingham, M. G., and Sandmo, A. (1972) 'Income Tax Evasion: A Theoretical Analysis', Journal of Public Economics 1.3-4: 323-338

Alm, J. and Liu, Y. (2017) Corruption, Taxation, and Tax Evasion, https://www.researchgate.net/publication/323080551_Corruption_taxation_and_tax_ev asion

Alm, J., Bloomquist, K. M. and McKee, M. (2015) 'On the External Validity of Laboratory Tax Compliance Experiments', Economic Inquiry 53.2: 1170-1186

Alm, J., Cherry, T., Jones, M. and McKee, M. (2010) 'Taxpayer Information Assistance Services and Tax Compliance Behavior', Journal of Economic Psychology 31.4: 577586

Besley, T. and Burgess, R. (2002) 'The Political Economy of Government Responsiveness: Theory and Evidence from India', The Quarterly Journal of Economics 117.4: 14151451

Besley, T. and Persson, T. (2014) 'Why Do Developing Countries Tax So Little?', The Journal of Economic Perspectives 28.4: 99-120

Central Bank of Nigeria (CBN) (2020) Quarterly Statistical Bulletin 9.2, June 2020

Chong, A., De La O, A. L., Karlan, D. and Wantchekon, L. (2015) 'Does Corruption Information Inspire the Fight or Quash the Hope? A Field Experiment in Mexico on Voter Turnout, Choice, and Party Identification', The Journal of Politics 77.1: 55-71

Cummings, R. G., Martinez-Vazquez, J., McKee, M. and Torgler, B. (2009) 'Tax Morale Affects Tax Compliance: Evidence from Surveys and an Artefactual Field Experiment', Journal of Economic Behavior \& Organization 70.3: 447-457

de Gramont, D. (2015) Governing Lagos: Unlocking the Politics of Reform, Washington, DC: Carnegie Endowment for International Peace

Duch, R. M., and Solaz, H. (2015) Why We Cheat: Experimental Evidence on Tax Compliance. Working Paper

Enachescu, J., Olsen, J., Kogler, C., Zeelenberg, M., Breugelmans, S. M. and Kirchler, E. (2019) 'The Role of Emotions in Tax Compliance Behavior: A Mixed-methods Approach', Journal of Economic Psychology74, 102194

Fischbacher, U. (2007) 'z-Tree: Zurich Toolbox for Ready-made Economic Experiments', Experimental Economics 10.2: 171-178 
Fjeldstad, Ø. D., Snow, C. C., Miles, R. E. and Lettl, C. (2012) 'The Architecture of Collaboration', Strategic Management Journal 33.6: 734-750

Goodfellow, T. and Owen, O. (2018) Taxation, Property Rights and the Social Contract in Lagos, ICTD Working Paper 73, Brighton: IDS

Guerra, A., and Harrington, B. (2018) 'Attitude-behavior Consistency in Tax Compliance: A Cross-national Comparison', Journal of Economic Behavior \& Organization 156: 184 205

Hallsworth, M., List, J. A., Metcalfe, R. D. and Vlaev, I. (2017) 'The Behavioralist as Tax Collector: Using Natural Field Experiments to Enhance Tax Compliance', Journal of Public Economics 148: 14-31

IMF (2018) Sub-Saharan Africa: Domestic Revenue Mobilization and Private Investment, IMF Regional Economic Outlook, April 2018

Kosec, K. and Wantchekon, L. (2020) 'Can Information Improve Rural Governance and Service Delivery?', World Development 125: 104376

Kettle, S., Hernandez, M., Ruda, S. and Sanders, M. (2016) Behavioral Interventions in Tax Compliance: Evidence from Guatemala, Policy Research Working Paper 7690, Washington DC: World Bank

Kirchler, E., Hoelzl, E. and Wahl, I. (2008) ,Enforced Versus Voluntary Tax Compliance: The "Slippery Slope" Framework', Journal of Economic Psychology 29.2: 210-225

Kosec, K. and Wantchekon, L. (2020) 'Can Information Improve Rural Governance and Service Delivery?', World Development, 125, 104376

Lefebvre, M., Pestieau, P., Riedl, A. and Villeval, M. C. (2015) 'Tax Evasion and Social Information: An Experiment in Belgium, France, and the Netherlands', International Tax and Public Finance 22.3: 401-425

Luttmer, E. F. and Singhal, M. (2014) 'Tax Morale', Journal of Economic Perspectives 28.4: 149-68

Mascagni, G. and Santoro, F. (2018) What is the Role of Taxpayer Education in Africa? African Tax Administration Paper 1, Brighton: IDS

Modugu, K. P. and Anyaduba, J. O. (2014) 'Impact of Tax Audit on Tax Compliance in Nigeria', International Journal of Business and Social Science 5.9: 207-215

Monteiro, V. (2018) 'Does the Planned Obsolescence Influence Consumer Purchase Decisions? The Effects of Cognitive Biases: Bandwagon Effect, Optimism Bias and Present Bias on Consumer Behavior', doctoral dissertation, Getulio Vargas Foundation, São Paulo School of Business Administration

Moore, M. (2004) 'Revenues, State Formation, and the Quality of Governance in Developing Countries', International Political Science Review 25.3: 297-319

Nigeria Natural Resource Charter (2019) 2019 Benchmarking Exercise Report, https://www.nigerianrc.org/2019-benchmarking-exercise-report/ 
Nigerian Bureau of Statistics and the Small and Medium Enterprises Development Agency (NBS and SMENDA) (2019). Micro, Small and Medium Enterprises (MSME) National Survey 2017 Report, Abuja: NBS and SMEDAN

OECD (2020) Tax on Personal Income, OECD Data, https://data.oecd.org/

OECD (2019) Revenue Statistics in Africa 2019 - Nigeria, http://www.oecd.org/tax/taxpolicy/revenue-statistics-africa-nigeria.pdf

Okello, A. (2014) Managing Income Tax Compliance through Self-assessment, Working Paper 14/41). International Monetary Fund

Okoye, D. (2020) 'Things Fall Apart? Missions, Institutions, and Interpersonal Trust', Journal of Development Economics, 148.C

Olalekan, F. (2020) 'FG Uses VAIDS to Raise N70 Billion from Nigerians', Nairametrics, 19 January, https://nairametrics.com/2020/01/18/fg-uses-vaids-to-raise-n70-billion-fromnigerians/\#: :text=The\%20Minister\%20of\%20Finance\%2C\%20Budget,over\%20N70\% 20 billion\%20from\%20Nigerians

Posner, E. A. (2000) 'Law and Social Norms: The Case of Tax Compliance', Virginia Law Review, 1781-1819

Grundmann, S. and Lambsdorff, J. G. (2017) 'How Income and Tax Rates Provoke Cheating - An Experimental Investigation of Tax Morale', Journal of Economic Psychology 63: 27-42

Sy, A. N. and Sow, M. (2016) Domestic Resources Mobilization, and External Financing: When Does Governance Matter? Evidence from sub-Saharan Africa, Africa Growth Initiative Working Paper 19, Washington DC: Brookings Institution

Tyler, T. R. (2006) 'Psychological Perspectives on Legitimacy and Legitimation', Annual Review of Psychology 57: 375-400

World Bank (2018) When Context Matters: Increasing Tax Payments in Poland, Washington DC: World Bank 